Int. J. Dev. Biol. 53: 1219-1234 (2009)

doi: $10.1387 / \mathrm{ijdb} .072456 \mathrm{jb}$

\title{
Plant Developmental Biology in Spain: from the origins to our days and prospects for the future
}

\author{
JOSÉ-PÍO BELTRÁN* \\ Instituto de Biología Molecular y Celular de Plantas (CSIC-UPV), Laboratorio de Biología del Desarrollo Floral, \\ Campus de la Universidad Politécnica de Valencia, Valencia, Spain
}

\begin{abstract}
The origins of modern Plant Developmental Biology in Spain can be traced back to a handful of scientists settled in Madrid, Barcelona, Valencia and Sevilla, who devoted themselves to plant biochemistry, molecular biology and genetics, and also to Drosophila developmental biology, which influenced, often unintentionally, the pioneers of this field. To reach the present day situation, the experience acquired in centres abroad has also been important, especially in plant research institutes in the USA, Germany (Max-Planck Institute für Züchtungsforschung) and United Kingdom (John Innes Centre). The contributions of Spanish scientists to the advancement of Plant Developmental Biology appears to be imbalanced towards reproductive biology, although relevant publications have also been reported on embryogenesis and seed development, shoot branching, tuberization, vascular morphogenesis, leaf development, regulation of development by light, signal transduction and hormone action and the connection between growth and development. Plant Developmental Biology in Spain is going through a flourishing time, with its future being highly dependent on i) appropriate funding conditions to its young scientists, ii) the opening of new areas of research, iii) the incorporation of technological breakthroughs into laboratories and iv) the carrying out of cooperative research by means of networking. Currently, besides many Departments of the Spanish universities, several centres in which competitive research in plant Developmental Biology can be accomplished, exist: the CNB and CBGP in Madrid, the LGMV CSIC-IRTA in Barcelona, the IBMCP CSIC-UPV, in Valencia and the IBVF CSIC-USE in Sevilla. Let's go for more!
\end{abstract}

KEY WORDS: Arabidopsis thaliana, seed size, shoot apical meristem, shoot branching, floral transition, tuberization, hormone action, circadian clock, symmetry, organ size and shape, vascular morphogenesis

The purpose of this review is to offer to the scientific community, especially to the youngest generation of scientists, an overview of the research situation in modern plant developmental biology in Spain. I present here, those who were the pioneers of the research carried out in this area, and the Centres and disciplines acting as Vavilov Centres of diversification of Spanish developmental biologists and the ones abroad that most contributed experience in different aspects of plant developmental biology to Spanish scientists. At the same time, I give notice of the main scientific accomplishments of Spanish plant developmental biologists mainly carried out in Spain but also abroad. Taken together, this approach should give the reader an idea about the strengths and weaknesses of this field and, therefore on what is needed for the future progress of Plant Developmental Biology research in Spain.

\section{Plant Developmental Biology}

The aim of Plant Developmental Biology is to understand how plants make themselves. Upon seed germination a shoot/root axis is established where growth is driven by shoot and apical meristems. The cells which make the plant body in many plant species are diploid, and that means that only after floral organ formation, which will give rise to reproductive development, plants

\footnotetext{
Abbreviations used in this paper: CBGP, Centro de Biotecnología y Genómica de Plantas; CNB, Centro Nacional de Biotecnología; IBMCP, Instituto de Biología Molecular y Celular de Plantas; IBVF, Instituto de Bioquímica Vegetal y Fotosíntesis; IRTA, Institut de Recerca I Tecnología Agroalimentàries; LGMV, Laboratori de Genètica Molecular Vegetal; UPV, Universidad Politécnica de Valencia; USE, Universidad de Sevilla.
}

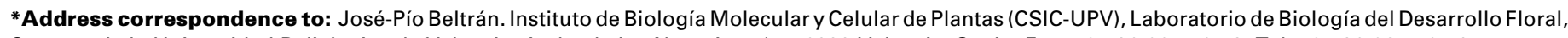
Campus de la Universidad Politécnica de Valencia, Avda. de los Naranjos s/n, 46022-Valencia. Spain. Fax: +34-96-387-78-59. Tel: +34-96-387-78-70. e-mail: jbeltran@ibmcp.upv.es 
do not have haploid cell germ lines. Plant shoots are constructed by repetition of units named phytomers which contain shoot internodes and leaves. Once plants are ready to reproduce themselves and given that the environmental conditions are appropriate, the floral transition takes place to allow pollen and ovules to be formed, pollination and fertilization leading to fruit and seed formation. Even if plants and animals share similar strategies for pattern formation in many developmental processes, knowledge of plant developmental cues are far behind for what we know of animal development. However, this is changing as fast as plant model systems, especially Arabidopsis thaliana, and other appropriated experimental tools to study development in plants have been selected and incorporated by researchers. Currently, the number of publications dealing with Arabidopsis increases and even exceeds the number of Droshophilapapers, a classical experimental system to study animal development. Therefore it is expected that important breakthroughs will be accomplished in those aspects of plant development that differ from animal development, such as the mode of action of molecules establishing morphogenetic gradients, the signal transduction pathways, or the measurement of time, quantity and quality of light, and the integration of those factors with gene developmental programs.

Barbara McClintock and Peter Peterson demonstrated the existence of mobile DNA which caused variegated phenotypic changes in colour in maize due to alterations in the expression of genes such as the $\mathrm{C}$ locus implicated in anthocyanin biosynthesis. First, that discovery allowed the isolation of unknown genes by tagging in plants (Paz-Ares et al., 1987) and opened the way to the use of mobile DNA in large scale plant genome insertion mutagenesis programs. That was possible thanks to the availability of plant genetic transformation systems driven by Agrobacterium tumefaciens. There is a plasmid fragment of Agrobacterium, the

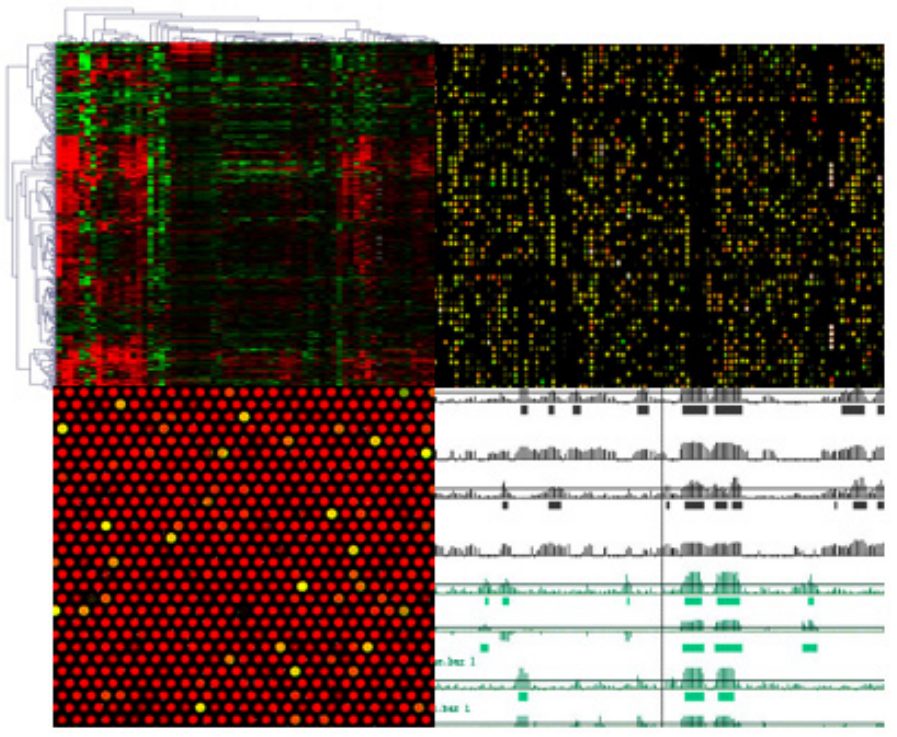

Fig. 1. The Genomics Unit at the CNB-CSIC (Madrid) provides support for genomic analysis to the Spanish research community. The figure shows a representative sample of the type of analyses offered that include "classical» microarrays, Tilling arrays, DNA/protein-binding arrays and data analysis, among others.
T-DNA, which can be transferred to the plant genome (Chilton et al., 1977). Plant scientists learned first to replace the T-DNA genes by selectable marker genes (Bevan et al., 1983; Zambrisky etal., 1983) and later by desired genes, and so they developed the T-DNA vectors for plant transformation used during the last decades. The study of plant development has become facilitated, especially in the last few years, because of the advance of genetic and genomic tools such as sequencing technology. Since the complete genome sequence of Arabidopsis thaliana was available in 2000 other genome sequences of model plants are available to the scientific community (Oryza sativa; Zea mays; Vitis vinifera) or are in progress to be completed (Medicago truncatula or Solanum licopersicon), while technologies recently developed such as pyrosequencing make it feasible to discover new genes or transcripts in cDNA libraries or undertake the sequencing of the genomes of individuals (Weber et al., 2007). Forward genetics has allowed the cloning, isolation and molecular characterization of plant developmental regulatory genes, especially in Arabidopsis thaliana (Somerville and Koornneef, 2002). Currently, the use of reverse genetic tools such as RNA interference, Targeting Induced Local Lesions in Genomes (TILLING), the development of Viral Induced Gene Silencing (VIGS) vectors for gene silencing together with large scale functional genomics, which use high density microarrays, allow an approach of systems biology to untangle plant developmental processes. A detailed general historical perspective of plant developmental biology has been recently published (see Van Lijsebettens and Van Montagu, 2005 and references therein).

\section{Plant Developmental Biology in Spain emerges from Plant Physiology, Biochemistry and Molecular Genet- ics}

Plant Developmental Biology has not been an academic discipline in Spain even if there are Departments of Biochemistry and Molecular Biology, Plant Physiology and Genetics at the Faculties of Biology, Chemistry, Pharmacy, and at the Agronomy Schools of Polytechnic Universities. Spanish researchers devoted to plant developmental biology have been recruited from people trained in those disciplines in Spain or elsewhere and just recently several Research Institutes, most of them belonging to CSIC, in which Plant Developmental Departments exists, have been created. If we consider the beginning of the modern Plant Developmental Biology linked to the discovery of mobile elements in maize around the fifties of the last century and the generalization of molecular genetic based approaches, when at the same time Spain was just starting to recover itself from a civil war which deprived the country of their best scientists, the limited contribution of science done in Spain to plant developmental biology is not a surprise. Even so, plant developmental researchers have benefited from the strength and high international level of the Biochemistry and Molecular Biology carried out in Spain (García Olmedo, 2004) while Plant Physiology has evolved less than Biochemistry and has remain separated from Botany as a discipline, and Plant Genetics has been almost restricted to Schools of Agronomy where it was more dedicated to traditional breeding than to modern biotechnologies. However, thanks to the tradition of Spanish biochemists and molecular biologists, it has been very common to send the best students for postdoctoral studies to 
laboratories around the world, where the principles of modern Plant Developmental Biology have been established.

Here I review the contribution of Spanish scientists to the establishment of milestones and technological breakthroughs by means of research performed both in Spanish laboratories or elsewhere, once they have been reintegrated to laboratories in Spain. This should give us an idea about the present situation and future perspectives of Plant Developmental Biology in Spain.

\section{Research Centres devoted to Plant Developmental Bi- ology in Spain}

Plant Developmental Biology laboratories are scattered among many universities in Spain, especially at Faculties of Biology and Agronomy. There are several research centres, in which at least one Department is devoted to Plant Developmental Biology studies or where the major scientific activity corresponds to this discipline, which were created in the last two decades. Those are the Centro Nacional de Biotecnología [National Biotechnology Centre], Campus de Cantoblanco, Figure1, (CNB, CSIC, Madrid) whose Department of Genética Molecular de Plantas was initially directed by Javier Paz Ares; the Instituto de Biología Molecular y Celular de Plantas [Institute of Plant Molecular and Cellular Biology], Figure 2, (IBMCP,CSIC-UPV) in Valencia which was designed and promoted by José Pío Beltrán and Vicente Conejero; the Instituto de Bioquímica Vegetal y Fotosíntesis [Institute of Plant Biochemistry and Photosynthesis] (IBVF, CSIC-U Sevilla) long time directed by Manuel Losada and the Laboratori de Genètica Molecular Vegetal [Plant Molecular Genetics Laboratory], Figure 3, (LGMV, CSIC-IRTA, Barcelona) a very ambitious research centre imagined and started up by Père Puigdomenech. The Universidad Politécnica de Madrid has created a new centre, long time ago thought by Pilar Carbonero and Francisco GarcíaOlmedo, and called the Centro de Biotecnología y Genómica de Plantas [Plant Biotechnology and Genome Centre], Figure 4, (CBGP, Madrid) which we expect to become one of the best plant research initiatives in Spain. Recently, the CSIC, together with the University of La Rioja and the regional government of La Rioja, have agreed to create the Instituto de Ciencias de la Vid y el Vino [Institute of Vine and Wine Sciences] (ICVV, La Rioja) which will dedicate efforts to generate basic knowledge, including some developmental studies, and applied knowledge on grapevine and its derived products. It is expected that the new installations will be ready along the next two-three years. The distribution along the Spanish geography of the above mentioned centres can be visualized in Figure 5.

\section{The scientists who founded Plant Developmental Biol- ogy in Spain}

Given the period of time covered by this review, from 1950 to 2007, I will try to identify at least three generations of Spanish scientists who have contributed to the emergence of Plant Developmental Biology in Spain.

\section{The first generation}

There is a handful of scientists who directly or indirectly through their disciples have influenced the establishment of a Spanish network of plant developmental biologists. These were:
Alberto Sols, biochemist (Madrid, CSIC-UAM) had influence over: Bartolomé Sabater, Ramón Serrano, Juan Carbonell, José Pío Beltrán, Antonio Vera, Pedro Carrasco; Miguel Angel Pérez Amador, David Alabadí, Miguel Angel Blázquez.

Juan Ramón Lacadena, geneticist (Madrid, UComplutense) had an influence on Alicia de la Peña, Juan Carlos del Pozo, Carlos Alonso-Blanco, Julio Salinas, Juan Capel, José Antonio Jarillo Francisco García Olmedo/ Pilar Carbonero, biochemists (Madrid, U Politécnica) had an influence on Cipriano Aragoncillo, Javier Paz Ares, Roberto Solano, Isabel Allona, Isabel Díaz, Montaña Mena, Joaquín Royo, Gregorio Hueros, Jesús Vicente-Carbajosa. Manuel Rosell, biochemist (Barcelona, UB) had an influence on Albert Boronat.

Antonio García Bellido/Juan Modolell/Carlos Alonso Bedate/Ginés Morata, Drosophila developmental geneticists (Madrid, CBMCSIC) had an influence on José Luis Micol, María Rosa Ponce, Pedro Robles, Victor Quesada, Soraya Pelaz, Albert Boronat, Pilar Cubas, Crisanto Gutierrez, Pedro Luis Rodríguez, Paula Suarez-López, Antonio Martínez Laborda, Montse Pagés, Jordi Gómez, Mercé Figueras, Mar Alba.

José Luis Oliver/Manuel Ruiz Rejón, geneticists (Granada, UG) had an influence on José Miguel Martínez Zapater, Juan Capel, María José Carmona, José Antonio Jarillo, Concepción Gómez Mena, Manuel Piñeiro, Rafael Lozano.

Jorge Fernández López Saez cell biologist (Madrid, CIB-CSIC) had an influence on María del Carmen Risueño, Miguel Vicente, Luis Cañas, Pilar Testillano, María José Carmona, Crisanto Gutierrez.

Xavier Avilés, biochemist (Barcelona, UAB) had an influence on Blanca San Segundo, Josep Casacuberta.

Jaume Palau, biochemist (Barcelona, CID-CSIC) had an influence on Pere Puigdomenech, Salomé Prat, Dolores Ludevid, José Antonio Martínez Izquierdo, Carlos Vicient, Matilde JoséEstañol.

Manuel Losada/Antonio Paneque biochemists (Sevilla, CSIC-U Se) had an influence on Juan Manuel Ramírez de Verger, Miguel García Guerrero, José María Vega, Carmen Fenoll, Juan Jordano, José María Romero, José León, José Carlos Reyes, Francisco Madueño, Javier Cejudo.

Francisca Fernández del Campo, plant physiologist (Madrid, UAM) had an influence on Carmen Fenoll, Laura Serna.

Eduardo Primo Yúfera, plant biochemist (Valencia, CSIC-UPV) had an influence on José Luis García Martínez, José Pío Beltrán, Antonio Granell, Isabel López, Jaime Martínez García, María Luisa Salvador, Manuel Rodríguez Concepción, Cristina Ferrándiz, Francisco Culiañez, Diego Orzaez.

Gregorio Nicolás, plant physiologist (Salamanca, USAL) had an influence on Dolores Rodríguez, Emilia Labrador, Oscar Lorenzo.

\section{Foreign research centres and scientists which have contributed to Plant Developmental Biology activities in Spain}

Following the tradition of the Spanish biochemists to send their best students to the best international research centres for postdoctoral studies, the same was done by the beginners of Plant Developmental Biology in Spain. Up to date, about two thirds of Spanish developmental biologists decided to investigate during their postdoctoral studies in Northamerican research cen- 
tres, especially those located in California. The other third visited European centres, mainly the Max-Planck Institut für Züchtungsforschung and the John Innes Centre.

\section{Northamerican research centres}

The Scripps Research Institute, La Jolla, California,USA. Steve Kay : David Alabadí, Paloma Más.

The Salk Institute for Biological Studies, La Jolla, California, USA. Detlef Weigel: Miguel Angel Blázquez, Juan Carbonell.

Chris Lamb: Antonio Leyva, Pablo Vera.

University of California, Berkeley, California, USA.

Wilhelm Gruissem: Juan Carbonell, Manuel Rodríguez Concepción

Patricia Zambryski/Sara Hake: Antonio Martínez Laborda

Peter Quail: Jaime Martínez-García.

University of California, San Diego, California, USA.

Marty Yanofsky: Montaña Mena, Pedro Robles, Cristina Ferrándiz,

Soraya Pelaz

Robert J.Schmidt, Montaña Mena, Jesús Vicente Carbajosa.

Maarten Chrispeels: Carmen Fenoll.

California Institute of Technology

Eric Davidson/Terry Thomas, Elliot Meyerowitz: Juan Jordano, José Luis Micol, María Rosa Ponce, José Luis Riechmann.

University of Pennsylvania Philadelphia, USA.

Anthony Cashmore: Juan Capel, Antonio Granell, José A. Jarillo. Michigan State University, East Lansing

Chris Somerville: José Miguel Martínez-Zapater.

University of Georgia, Athens, USA.

Russell L. Malmberg: Luis Antonio Cañas.

\section{European Union}

Max Planck Institut für Züchtungsforschung, Köln, Germany. Heinz Saedler/Hans Sommer, Francesco Salamini/ Richard Thompson: José Pío Beltrán, Javier Paz Ares, Marcos EgeaCortines, Rafael Lozano, Gregorio Hueros.

John Innes Centre, Norwich, UK.

Cathie Martin, Enrico Coen, David Baulcombe, Caroline Dean, George Coupland, Robert Sablowsky: Pilar Cubas, José María Romero, Jaime Martínez García, Javier Cejudo, Victor Quesada, Paula Suárez,

Laboratory of Genetics, Wageningen University, The Netherlands.

Maarten Koornneef: Carlos Alonso-Blanco.

Institut für Genbiologische Forschung, Berlin, Germany. Lothar Willmitzer: Salomé Prat, José Juan Sánchez Serrano.

\section{Major contributions to Plant Developmental Biology made by Spanish scientists}

Contributions have been arranged thematically for a better comprehension.

\section{Seed size, embryogenesis and seed development}

Carlos Alonso Blanco, working with Maarten Koornneef at Wageningen, The Netherlands, studied the natural allelic variation of seed size loci in relation to other life history traits of Arabidopsis. Using a recombinant inbred line population derived from Ler and Cvi, they mapped quantitative trait loci (QTLs) affecting twelve life history traits related to seed size, fruit size and seed number. They were six putative seed size QTLs that did not show a significant effect on any other trait, suggesting that this allelic variation may specifically be involved in seed development processes (Alonso-Blanco et al., 1999). This genetic characterization of plant resources should be fundamental to elucidate the molecular and cellular mechanisms which underline seed development and seed size. Currently, Carlos Alonso Blanco works at the Departamento de Genética Molecular de Plantas (CNB, CSIC, Madrid). He has established very valuable tools to carry out plant developmental studies such as a permanent mutant collection of Arabidopsis thaliana Landsberg erecta ecotype and an efficient service for TILLING. Carlos Alonso-Blanco maintain an active cooperation with the Koornneef laboratory to develop genetic tools that could be used for developmental studies. They have developed a near isogenic line population of Arabidopsis thaliana to reinforce QTL mapping capabilities of a previous generated recombinant inbred line population (Keurentjes, et al., 2007).

Père Puigdomenech is one of the major protagonists in the Spanish scene concerning plant molecular biology. He has been leading a large group of plant scientists at the Centro de Investigación y Desarrollo, CSIC, Barcelona. Recently, he was successful when he started a very ambitious initiative to form the Laboratori de Genètica Molecular Vegetal CSIC-IRTA which will integrate plant scientists from the universities of Barcelona, Autónoma de Barcelona and Lleida. That would generate the largest centre in Spain devoted to plant studies. Puigdomènech participated in the international initiative of sequencing the genome of Arabidopsis thaliana that ended successfully in 2000, and nowadays, he is responsible of an initiative for functional genomics in melon. Puigdomènech together with Dolores Ludevid and Carlos Vicient have used maize as a model plant to study embryo differentiation. They described the accumulation of cell wall hydroxyproline-rich glycoprotein mRNA as an early event in maize embryo cell differentiation (Ruiz-Avila, et al., 1992) and isolated the HPRPgene to study its expression in scutellum and in non-vascular cells from the embryo axis that allowed them to propose different functional hypotheses (José-Estañol, et al., 1992). Later on, with the contribution of the promising and early passed away Spanish scientist Virginia Stiefel, they were able to clone TM20, a gene coding for a new class of transmembrane protein expressed in the meristematic tissues of maize (Stiefel et al., 1999). Montserrat Pagés is the senior scientist who has most contributed with Puigdomènech to make the Laboratori Genética Vegetal, CSIC-IRTA, Barcelona the one with most initiatives to study plant developmental biology in Spain. She has been long time interested in the understanding of the molecular basis of ABA action during maize embryogenesis and embryo dessication. She pioneered the field, reporting the cloning of a gene coding for a glycine rich protein induced by ABA in the maize embryo (Gómez et al., 1988). Later on, her group has made important contributions in the elucidation of the function of the ABA-responsive proteins such as Rab17, a protein present in all cells of embryo tissues that may play a role in nuclear protein transport, and in the mode of action of that plant hormone (Goday etal., 1994). She has shown that ABA and the transcriptional activator VIVIPAROUS1 have a synergistic effect on transcription during embryo development, analyzing their interaction with the abscissic acid responsive element (ABRE) of the maize rab28gene (Busk and Pagés, 1997). Today Montserrat Pagés is a recognized expert on the 
molecular mode of action of ABA. Pilar Carbonero (Departamento de Biotecnología, U Politécnica de Madrid) is an expert on the role of cereal seed proteins. She has been long time studying the cis regulatory elements and the transacting factors of the ABA response of hydrolase genes upon germination of seed cereals. They have isolated two genes from barley encoding DOF transcription factors, HvDof17and HvDof19and found that HvDOF17 binds in a specific manner to a thiol-protease gene (A/21), and mediates the $A B A$ repression of that gene in the barley aleurone. The transcripts of the two transcription factors accumulate early in germinating aleurones, whereas the mRNAs of the GA-induced activator GAMYB remains little expressed. Those findings and others have allowed Carbonero and co workers to propose a model of hydrolase gene expression upon seed germination (Díaz et al., 2002; Moreno-Risueño et al., 2007).

Dolores Rodríguez, Emilia Labrador, Gregorio Nicolás and more recently Oscar Lorenzo (Departamento Fisiología Vegetal, U Salamanca) have been long-time working on seed germination. Together with Pedro Luis Rodríguez, they isolated a protein phosphatase type 2C from Fagus sylvatica that becomes upregulated upon addition of $A B A$ to seeds and during early weeks of stratification as well, and studied the role of that protein on the regulation of $\mathrm{ABA}$ responses in dormancy and germination by means of transgenic Arabidopsisplants expressing constitutively FS PP2C1. 'Gain of function of FS PP2C1 was sufficient to confer ABA insensitivity in seed dormancy and germination, and the transgenic plants show $A B A$ resistant early root growth and diminished induction of the ABA-response genes $R A B 18$ and $K I N 2$, all this suggesting a role for Fs PP2C1 as a negative regulator of ABA signalling in seeds (González-García et al., 2003). More recently Pedro Luis Rodríguez has shown cooperative negative regulation of $A B A$ signalling by $A B A-I N S E N S I T I V E 1$ and HYPERSENSITIVE TO ABA1, two protein phosphatases type 2C of Arabidopsis (Saez et al., 2006).

Javier Cejudo (Instituto de Bioquímica Vegetal y Fotosíntesis, CSIC-U Sevilla) leads a group interested in the understanding of the mode of action of gibberellins during seed germination in cereals. Recently, they have reported that GA induces a nuclease in the nucleus of wheat aleurone cells undergoing programmed cell death (Domínguez et al., 2004). Juan Jordano and Concepción Almoguera, IRNASE, CSIC, Sevilla, were interested in the study of embryogenesis in sunflower. They isolated genes coding for heat shock proteins, trying to uncover alternative functions of those genes in the plant cell (Almoguera and Jordano, 1992). They have reported the cloning and functional characterization of $\mathrm{HaHsFA9}$, the first heat-schock transcription factor that is specifically expressed during embryogenesis of sunflower. They proposed that this transcription factor is implicated in the developmental activation of genes such as Hahsp17.6G1 and in similar target genes such as Hahsp17.7G4 (Almoguera et al., 2002). Gregorio Hueros (Departamento de Biología Celular y Genética, U. Alcalá) worked with Francesco Salamini and Richard Thompson in the Max-Planck-Institut für Züchtunsforschung on maize endosperm patterning. Later on, Gregorio Hueros has established a group together with Elisa Gómez and Joaquín Royo in Spain. They reported the isolation of $Z m M R P$-1 a MYB transcription factor which is expressed specifically in endosperm transfer cells, accumulating at the basal pole of the endosperm coenocyte soon after fertilization. ZmMRP-1 is localized in nuclei and can transactivate the promoters of transfer ell-specific genes (Gómez et al., 2002).

\section{Shoot apical meristem and shoot branching}

Pilar Cubas joined the Centro Nacional de Biotecnología, CSIC Madrid after working for years on flower symmetry with Enrico Coen at John Innes Centre, UK. She has started a laboratory currently dedicated to the study of shoot branching. Shoot branching depends on whether axillary buds grow out to give a branch or they remain dormant in the axils of leaves. Pilar Cubas and co-workers have isolated BRC1 an Arabidopsis gene coding for a TCP transcription factor closely related to teosinte branched1(tb1) from maize. BRC1 is expressed in developing


Fig. 2. The Institute for Plant Molecular and Cell Biology (IBMCP, CSIC-UPV) in Valencia. Facilities here allow the growth of transgenic plants under environmentally controlled conditions allowing massive reverse genetic experimental strategies. 
buds, where it arrests bud development. $B R C 1$ downregulation leads to branch development. $B R C 1$ appears to act downstream of the MORE AXILLARY GROWTHpathway that it is required for auxin induced apical dominance. Pilar Cubas suggests that the conservation of $B R C 1 /$ tb 1 function among distantly related angiosperm species might indicate that a single ancestral mechanism of branching control integration evolved before the radiation of flowering plants (Aguilar-Martínez et al., 2007)

\section{Vascular morphogenesis}

Antonio Leyva (Departamento de Genética Molecular de Plantas, Centro Nacional de Biotecnología, CSIC, Madrid) is interested in the study of the molecular mechanisms involved in the inception of vascular morphogenesis. Perhaps this interest began while he was working with Chris Lamb at the Salk Institute, California when they characterized the role of the phenylalanine ammonia-lyase gene 2 in the early stages of vascular development at the inception of xylem differentiation. They proposed that the PAL2 promoter had a modular organization and that tissuespecific expression in the vascular system may provide a flexible mechanism for tissue specificity (Leyva et al., 1992). Recently, Leyva and co-workers have provided genetic and molecular evidence for independent pathways of the proliferation of vascular initials and canonical cytokinin signalling in Arabidopsis (GarcíaPonce de León et al., 2004). Pablo Vera (IBMCP CSIC-UPV, Valencia) worked also as a postdoctoral fellow with Chris Lamb in California. Although his main scientific interest consists in the understanding of plant defence mechanisms against pathogens, he has made some significant contributions to plant development, such as the discovery of a plant homeobox gene which is expressed specifically at the phloem during secondary phases of vascular development (Tornero et al., 1996). Ana Caño-Delgado (Laboratori Genética Vegetal, CSIC-IRTA, Barcelona) has recently started a group to study novel components in phloemprovascular patterning in Arabidopsis.

\section{Leaf development}

A systematic molecular and genetic analysis of leaf development in Arabidopsis thaliana was initiated a decade ago by José Luis Micol and María Rosa Ponce (Division de Genética, U Miguel Hernández, Elx). José Luis Micol is interested in the study of leaf ontogeny as a model for answering general questions for pattern formation. To this end, Micol and co workers isolated Arabidopsis variants showing abnormal venation pattern, marginal configuration, shape or size of their vegetative leaves. Variations in the repeat number at 22 microsatellite loci were determined with the purpose of assessing correlation between the phylogeny of the accessions studied and leaf morphology (Pérez-Pérez, et al., 2002). For the causal analysis of plant leaf development they have performed a large scale screen for EMS-induced mutants to define the spectrum of possible perturbations in leaf morphogenesis, in order to determine the number of genes whose mutations disturb the process and consequently this allowed the selection of some mutants for the molecular characterization of the leaf development control (Berná, et al., 1999). As an example, among many, of the molecular characterization of the mutants isolated, they have described that the HVE/CAND1gene is required for the early patterning of leaf venation in Arabidopsis and that ubiquitin mediated auxin signalling is required for venation patterning in

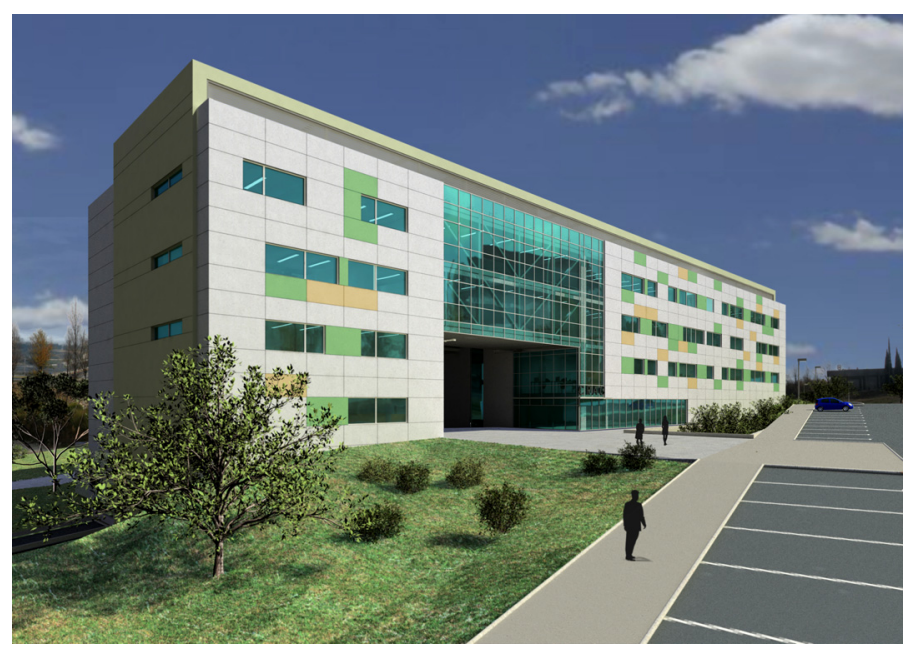

Fig. 3. Building of the Centre for Research on Agricultural Genomics, CSIC-IRTA-UAB. This is under construction in the campus of the Autonomous University of Barcelona, where the groups of the Molecular Genetics Department (IBMB-CSIC) will be hosted from the middle of 2009

laminar organs. Double mutant and transgenic plants indicated that auxin transport and perception act independently to pattern leaf veins (Alonso-Peral et al., 2006). José Luis Micol has also demonstrated a high capacity for networking helping the Arabidopsis Spanish community through an efficient service for gene mapping. Carmen Fenoll (UCLM, Toledo) was able to raise a laboratory while working at UAM, Madrid, devoted to study the ontogeny of stomatal clusters in Arabidopsis leaves. By using growth conditions which limit gas exchange with the atmosphere, she realized that stomatal clusters look like phenocopies of those showed by four lips and too many mouths mutants, suggesting that stomata spacing is under environmental as well as genetic control. Fenoll traced the origin of those clusters by following promoter activity for genes that served as markers of competence in cell division, mitotic activity and guard mother cell and developing guard cell identity. It was concluded that that stomatal clusters derive from a single protodermal cell through a process which involves changes in cell fate in a subset of subsidiary cells (Serna and Fenoll, 1997; Serna et al., 2002).

\section{Floral transition}

Floral transition, flower and fruit development are topics on which Spanish developmental biologists have made numerous and relevant contributions, both in Spanish laboratories and abroad. According to García Olmedo, the studies on plant developmental biology were initiated in Spain by José Miguel Martínez-Zapater (Madrid, INIA) with respect to flowering, José Pío Beltrán (IBMCP CSIC-UPV, Valencia) regarding flower and fruit development and later on by José Luis Micol (U Miguel Hernández , Elx) with respect to leaf development. Floral transition is a process that has to be repressed until plants are mature to build flowers able to produce fruits and seeds. Therefore floral transition has to integrate a developmental genetic program with environmental factors such as photoperiod, exposure to cold temperatures (vernalization), humidity and nutrient availability among others. The genetic analysis of flowering time mutants allowed the distinction of four major genetic pathways, the photo- 
period and the vernalization pathways mediating the response to environmental factors and the autonomous and the gibberellin (GA) pathways that are largely independent of external signals (Martínez Zapater et al., 1994; Martínez Zapater et al., 1995; Parcy, 2005). A large number of genes acting within those pathways have been cloned and efforts are currently devoted to understand how they are interacting with each other and what are the functions of the gene products. The CONSTANSgene is the most downstream gene known for the photoperiod pathway and both the light and the internal clock regulate the accumulation of CO (Suárez-Lopez et al., 2001; Valverde et al., 2004). The FLOWERING LOCUS C gene marks the convergence between the autonomous and vernalization pathways. CO activity and repression of FLC trigger the flowering signals leading to the induction of floral meristem identity genes such as $\angle E A F Y$, APETALA1 and CAULIFLOWER. However, salicylic acid regulates flowering time in a process that involve the photoperiod and autonomous pathways, but it does not require the function of the flowering genes CONSTANS or FLOWERING LOCUS $C$, as shown by José León from IBMCP CSIC-UPV, Valencia (Martínez et al., 2004). There are three genes shown to integrate the effects from the different floral pathways, $\angle E A F Y$, FLOWERING LOCUS Tand SUPPRESSOROFCOOVEREXPRESSION(Parcy, 2005). Martínez-Zapater / Julio Salinas and co-workers analyzed double mutants combining late-flowering mutations at four floweringtime loci ( $F V E, F P A, F W A$ and $F T$ ) with mutations at the $\angle E A F Y$, APETALA1 and TERMINAL FLOWER1 loci involved in the floral initiation process. That work was fundamental to understand the different roles of flowering time genes in the activation of floral initiation genes in Arabidopsis (Ruiz-García et al., 1997). More recently, this team characterized, at a molecular level, FVE, a component of the autonomous pathway that encodes At MSI4, a putative retinoblastoma-associated protein. They have also shown that FVE participates in a protein complex repressing $F L C$ transcription and consequently, it uncovered a new genetic mechanism in the regulation of flowering (Ausín, et al., 2004). In collaboration with George Coupland they have characterized the product of EARL Y BOL TING IN SHORT DAYS as a chromatin remodelling factor that regulates flowering in Arabidopsis by repressing FT(Gómez-Mena et al., 2001; Piñeiro et al., 2003). Carlos Alonso-Blanco working with Maarten Koornnef at Wageningen utilized a QTL mapping approach in recombinant inbreed lines to identify and locate the loci responsible for the flowering variation in three environments differing in photoperiod length and/or vernalization treatment. The four largest effect QTLs were characterized genetically and physiologically in relation to flowering responses to day length and vernalization (AlonsoBlanco et al., 1998). Further work of these authors allowed the molecular characterization of the ED/QTL as a novel allele of $C R Y$ 2,encoding the blue-light photoreceptor cryptochrome-2 (ElAssal et al., 2001).

While working at the laboratory of Detlef Weigel in California, Miguel Angel Blázquez (IBMCP CSIC-UPV, Valencia) contributed greatly to reveal that the expression pattern of the floral meristem identity gene $\angle E A F Y$ precedes the floral transition, and is firstly detected in young leaf primordia and then increasing to a maximum in young floral meristems (Blázquez et al., 1997). Moreover he showed that gibberellins promote flowering in Arabidopsis by activating the $\angle E A F Y$ promoter (Blázquez et al.,
1998). The functionality of the Arabidopsis LEAFY and APETALA1 in heterologous systems has been demonstrated by Leandro Peña and Luis Navarro (IVIA, Valencia) in cooperation with José Miguel Martínez-Zapater, by means of the constitutive expression of those genes in transgenic citrus trees, which greatly reduced their generation time (Peña et al., 2001).

As I said at the beginning of the molecular genetic analysis of flower development there were two plant model systems that were amenable to this kind of analysis: Antirrhinum majus and Arabidopsis thaliana. Like in the case of class B genes necessary for the identity of petals and stamens, which were first isolated in Antirrhinum (Sommer et al., 1990), the same happened with the FLORICAULA, a key gene regulating flowering induction which was isolated in 1990 by José María Romero IBVF, Sevilla (Coen et al., 1990) while working with Enrico Coen at the John Innes Centre, Norwich, UK. Later, LEAFY the FLORICAULA ortholog in Arabidopsis was characterized by George Haughn (Schultz and Haughn, 1991) and Detlef Weigel (Weigel et al., 1992). María José Carmona (Departamento de Biotecnología, U Politécnica Madrid), in collaboration with José Miguel Martínez-Zapater, is leading a group which have characterized $V F L$, the grapevine FLORICAULA ortholog (Carmona et al., 2002). They have shown that floral meristem identity genes are expressed in the tendrils of grapevine providing molecular support to the hypothesis that Vitis tendrils are modified reproductive organs adapted to climb (Calonje et al., 2004); and they have characterized the FT/TFL1 gene family in Vitis vinifera suggesting a role for $V V F T$ and $V V M F T$ as flowering promoters, while VVTFL 1A, VVTFL 1Band TFL 1Ccould be associated with vegetative development and maintenance of meristem indetermination (Carmona et al., 2007). María Herrero (Estación Experimental Aula Dei, Zaragoza) is one of the few Spanish scientists that has used a cellular approach to dissect a developmental process, namely the regulation of mating in flowering plants. Synchronous development of the male and female sexual organs persists after pollination, with both pollen and pistil following complex but highly integrated pathways that allow fertilization to take place. When a lack of synchrony occurs, it might be used as a powerful tool to investigate the regulation of mating (Herrero, 2003 and references therein).

\section{Flower development}

Flowers are composed of sepals, petals, stamens and carpels arranged in concentric whorls. The genetic control of floral organ identity was a major discovery of plant developmental biology. The so called ABC model states that three types of biological activities are necessary for floral organ identity. Genes coding for A activity specify sepal formation in the first whorl; in the second whorl, where petals are formed, the products of genes coding for $A$ and $B$ activities have to be expressed; for stamen specification at the third whorl, $\mathrm{B}$ and $\mathrm{C}$ activities are required, and finally at the fourth whorl, only $\mathrm{C}$ activity is expressed specifying carpel formation (Coen and Meyerowitz, 1991). Ten years later Soraya Pelaz (Laboratori Genética Vegetal, CSIC-IRTA Barcelona), while working at Marty Yanofsky's laboratory demonstrated that $\mathrm{B}$ and $\mathrm{C}$ floral organ identity functions require SEPALLATA MADS-box genes (Pelaz et al., 2000). The participation of SEPALLATA genes as necessary partners to specify floral organ identity has led to a revised $A B C$ model: the floral quartet model (Robles and Pelaz, 2005). 
The garden pea began to be used as a model system, not for legumes but for citrus, in Valencia by José Luis García-Martínez and Juan Carbonell, IBMCP CSIC-UPV, Valencia (García-Martínez and Carbonell, 1980). Spraying with GA was an agronomic practice in valencian orchards to reinforce fruit set in citrus. Gibberellins are able to induce parthenocarpic fruit set and development in Pisum sativum and the aim of their initial work was to understand the role of the plant hormones on fruit growth, size and shape. Later on, José Pío Beltrán joined the task focusing his work on the physiological and biochemical bases, especially on the role of gibberellins and sucrose on carpel and fruit development (Peretó and Beltrán, 1987; Janhke et al., 1989; Estruch and Beltrán, 1991; GarcíaMartinez and Beltrán, 1992; Rodríguez-Concepción and Beltrán,

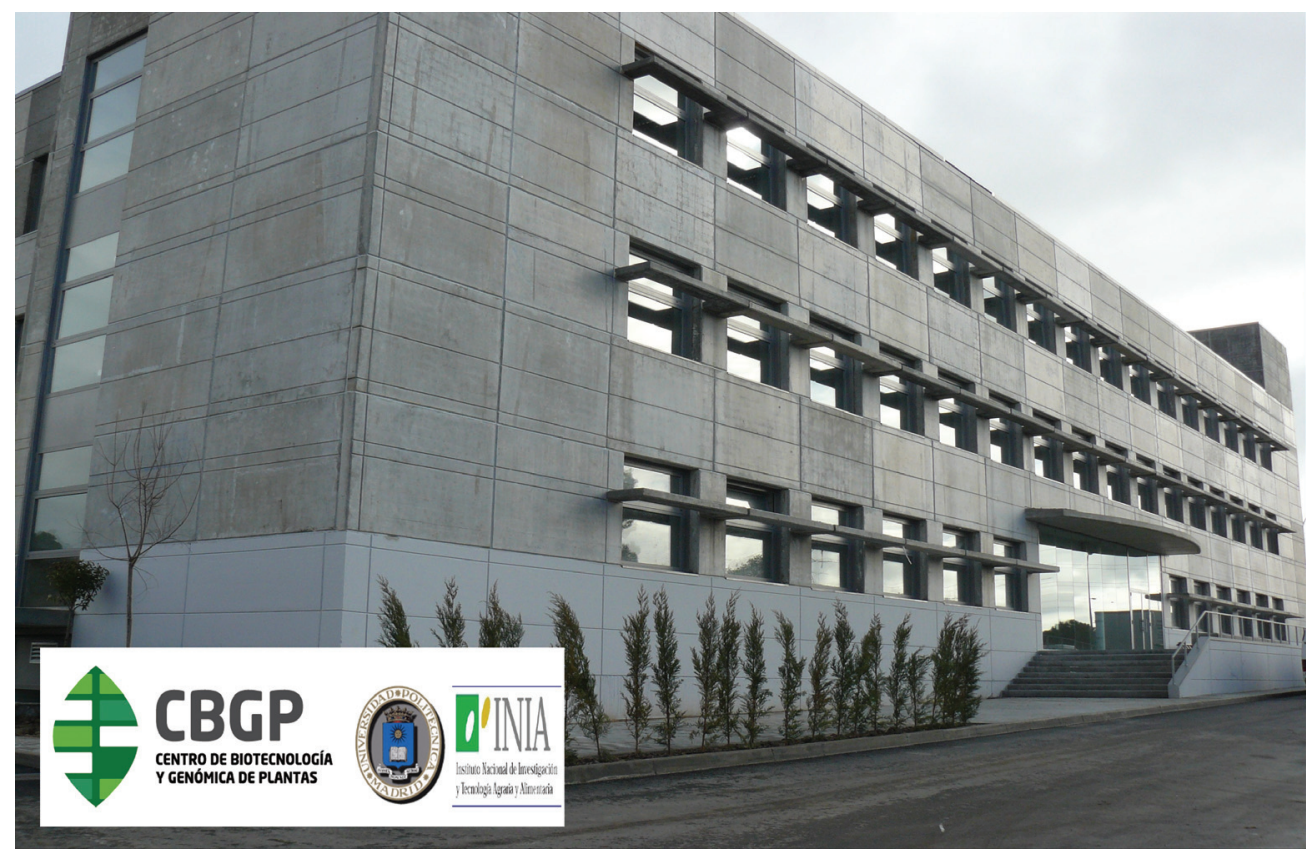
1995; Rodríguez-Concepción etal.,

Fig. 4. Plant Biotechnology and Genome Centre (CBGP, UPM-INIA). This Institute located at the Campus of Montegancedo, Madrid, opened its doors in the Autumn of 2008.

2001) while Juan Carbonell, together with Pedro Carrasco (UVEG), Antonio Granell from IBMCP UPV-CSIC, Valencia and Miguel A. Pérez-Amador from IBMCP CSIC-UPV, Valencia dedicated their efforts to understand the role of polyamines and proteases in fruit senescence as a process alternative to development (Granell et al., 1992; Perez-Amador et al., 1995; Orzaez and Granell, 1997; Acosta et al., 2005). José Luis García-Martínez, with the collaboration of Isabel López, has pursued his work on gibberellins in which he is a worldwide recognised expert (García-Martínez et al., 1997; Fos etal., 2000). At the end of the eighties, the necessity to incorporate the molecular genetic analysis to make progress in the understanding of flower and fruit development was evident. To this end, José Pío Beltrán joined the laboratory of Heinz Saedler and Hans Sommer at Max Planck Institut für Züchtungsforschung in Köln. The cue was to incorporate the use of floral homeotic mutants. A key model plant for developmental studies in Europe was Antirrhinum majus due to the possibility to carry out transposon gene tagging experiments. As it is often the case in many key discoveries in science, there was a friendly competition between Enrico Coen from John Innes Centre at Norwich and Heinz Saedler to characterize the DEFICIENS gene, whose loss of function causes the homeotic transformation of petals into sepals and of stamens into carpels. Thanks to the ability of Hans Sommer at Max Planck Institut, we cloned DEFICIENS, the first floral homeotic gene characterized (Sommer et al., 1990). Immediately, the cloning of $A G A M O U S$ from Arabidopsiswas reported by Elliot Meyerowitz. The initials of both genes are included in the acronym to designate the MADS-box gene family with over one hundred members responsible of the control of many plant development processes in Arabidopsis, with only a few MADSbox genes also in yeast (MCM1) and in humans (SERUM RESPONSE FACTOR).

Montaña Mena (UCLM, Toledo), when she was with Bob
Schmidt in San Diego, California used reverse genetics to isolate a transposon induced mutation in $Z A G 1$ the maize homolog of AGAMOUS of Arabidopsis. Only determinacy but not reproductive floral organ identity was affected in this mutant. That led to the identification and cloning of a second AGAMOUShomolog ZMM2 suggesting that $\mathrm{C}$-function organ identity in maize is accomplished by two closely related genes, ZAG1 and ZMM2 with overlapping but non identical activities (Mena etal., 1996). Marcos Egea-Cortines (U Cartagena) who worked at Hans Sommer/ Heinz Saedler laboratory made an important progress into the molecular mode of action of MADS-box proteins demonstrating the formation of protein ternary complexes such as the one between SQUAMOSA, DEFICIENS and GLOBOSA, implicated in the control of floral architecture in Antirrhinum majus (Davies et al., 1996; Egea-Cortines et al., 1999). The same floral organs are quite different among plant species. Despite the characterization of the genes controlling floral organ identity, knowledge on the genes controlling floral organ size and form remain elusive to researchers. Marcos Egea-Cortines had the courage to start a group in Spain to study the developmental genetic bases of floral organ size (Weiss et al., 2005). José Pío Beltrán incorporated into his laboratory in Valencia molecular genetic analyses to the study of floral development in legumes (Beltrán, 1991; Beltrán et al., 1996; Ferrándiz et al., 1999a; Berbel et al., 2001; Benlloch et al., 2003; Berbel et al., 2005; Hecht etal., 2005; Benlloch etal., 2006). To understand the regulation of floral ontogeny and flower development of legumes further important work has been developed by Luis Cañas from IBMCP CSIC-UPV as well Cristina Ferrándiz, which later on made outstanding contributions on fruit development in Marty's Yanofsky laboratory (Ferrándiz et al., 1999b; Ferrándiz et al., 2000a; Ferrándiz et al.,2000b), and Francisco Madueño from IBMCP CSIC-UPV, Valencia, currently devoted to study the regulation of TERMINAL FLOWER1, a gene controlling 
Arabidopsis plant architecture in collaboration with Desmond Bradley. Further cooperation between Francisco Madueño, Cristina Ferrándiz and José Pío Beltrán has allowed the cloning of PS MADS10, a pea gene whose mutation corresponds to the mutant vegetative 1 that exhibits a unique non-flowering phenotype not found in model species: the secondary inflorescence meristems are replaced by vegetative shoots (Madueño et al., 2006). The control of floral initiation and inflorescence architecture in different plant species has been reviewed by Francisco Madueño ( Benlloch et al., 2007).

Albert Boronat (Departament de Bioquímica, U Barcelona) leads a group of plant biochemists that have made significant contributions for understanding isoprenoid biosynthesis. That complex, multibranched pathway proceeds through mevalonate synthesis to produce relevant compounds for developmental processes such as carotenoids, gibberellins, cytokinins, abscisic acid, and chlorophyls among others. Boronat and co-workers, characterized the expression patterns of 3-hydroxy-3methylglutaryl coenzyme $A$ reductase genes, coding for the enzymes catalyzing the rate-limiting step of mevalonate in Arabidopsis (Enjuto, et al., 1995). That group was reinforced by the incorporation of Manuel Rodríguez-Concepción. They showed the regulatory role of 1-deoxy-D-xylulose 5-phosphate synthase gene on carotenoid biosynthesis during tomato fruit development (Lois et al., 2000) and demonstrated at genetic and biochemical levels that the two pathways for isoprenoid precursors, the cytosolic mevalonic acid pathway and the plastidial methylerythritol phosphate pathway, share common precursors that are interchanged, and that distinct light perception and signal transduction pathways coordinate the crosstalk between cell compartments for isoprenoid biosynthesis during the first stages of seedling development in Arabidopsis (Rodríguez-Concepción etal., 2004; SauretGueto et al., 2006). Recently Manuel Rodríguez Concepción has established his own laboratory at the Laboratori de Genética Vegetal CSIC-IRTA, Barcelona).

MADS-box genes in relation to flower and fruit formation in Solanum esculentum, a model plant of agronomic interest, have been studied by Rafael Lozano and his laboratory (U de Almería). They were able to correlate abnormalities in tomato flower development with changes in expression of MADS-box genes (Lozano et al., 1998) and to isolate SINGLE FLOWER TRUSS a gene controlling the transition and maintenance of flowering in tomato and to characterize the tomato falsiflora mutant. FALSIFLORA corresponds to the $\angle E A F Y / F L O R I C A U L A$ genes of the plant model systems Arabidopsis/Antirrhinumand controls both flowering time and floral meristem identity in tomato (Molinero-Rosales et al., 1999). Recently, Antonio Granell from IBMCP (Valencia) is coordinating a functional genomics initiative for tomato and they are developing breakthrough technologies such as agroinjection of tomato fruits to carry out rapid functional analysis of transgenes directly in fruit (Orzaez, et al., 2006). They have uncovered that fruit set and early fruit development in tomato is controlled by a single DELLA gene (Martí, etal., 2007). Finally, Antonio MartínezLaborda and Antonio Vera (U de Alicante), with the collaboration of Cristina Ferrándiz, have carried out a smart mutant analysis to show that leaf and fruit patterning share common regulatory networks (Ripoll et al., 2006). According to them, pattern formation along the mediolateral axis of the ovary giving rise to three domains, replum, valve margin and valve, is specified by the opposing gradients of two antagonistic factors, valve factors and replum factors, with the class I KNOX genes working as replum factors (Alonso-Cantabrana et al., 2007).

\section{Symmetry, organ size and shape}

Pilar Cubas while working at The John Innes Centre, UK with Enrico Coen was able to characterize at molecular level a naturally occurring mutant of Linaria vulgaris, described by Linnaeus in which the fundamental symmetry of the flower is changed from bilateral to radial. The mutant carries a defect in $L c y c$ a homologue of the cycloideagene which controls dorsoventral asymmetry in Antirrhinum. The $\angle y c$ gene was extensively methylated and was transcriptionally silent in the mutant, and that modification is heritable and co-segregates with the mutant phenotype. Those observations indicate that epigenetic mutations may play a significant role in evolution (Cubas et al., 1999). Later on, after being incorporated into the Centro Nacional de Biotecnología, Pilar Cubas found that the cycloideagene is expressed asymmetrically in floral meristems, even though they are destined to form symmetrical flowers as occurs in the case of Arabidopsis. That suggested although the flowers of the common ancestor were probably radially symmetrical, they may have had an incipient asymmetry evident at the level of early gene activity, which could have been recruited many times during evolution to generate asymmetric flowers (Cubas et al., 2001)

\section{Root development}

Studies on root development by Spanish developmental biologists are scarce. Recently, Carmen Castresana (Departamento de Genética Molecular de Plantas, Centro Nacional de Biotecnología, CSIC, Madrid) has proposed that oxylipins from the 9-Lipoxygenase pathway might function in cell wall modifications required for lateral root development and pathogen arrest. Her group has carried out the molecular genetic analysis of noxy2 (nonresponding to oxylipins2) an insensitive mutant to 9Hydroxyoctadecanetrienoic acid, that is a potent inducer of root waving, and coronatine insensitive 1-1 (jasmonate insensitive), revealing that, at least three signalling cascades mediate oxylipin actions (Vellosillo et al., 2007). Regulation of the basic mechanisms of monovalent cation transport in plants is largely unknown despite its importance for nutrient uptake, metabolism, cellular integrity, cell death, growth and differentiation. Recently, Ramón Serrano (IBMCP, CSIC-UPV, Valencia) and co-workers have identified and cloned in Arabidopsis a quiescin-sulfhydryl oxidase (QSO) regulating cation homeostasis at the root symplast-xylem interface. A plausible mechanism of QSO action consists of the activation of root systems loading $\mathrm{K}+$ into xylem, but different from the SKOR channel, which is not required for QSOs action (Alejandro et al., 2007).

\section{Tuberization}

One Spanish developmental biologists who has most contributed to Plant Developmental Biology is Salomé Prat (Departamento de Genética Molecular de Plantas, Centro Nacional de Biotecnología, CSIC, Madrid). Tubers are modified underground stems with very short internodes bearing scale leaves subtending the dormant axillary buds. Tubers are unique to some Solanum species and serve as storage organs and as a vegetative propagation system. Salomé Prat isolated PHOR1 from Solanum 
tuberosum andigena, a plant forming tubers under short day conditions. Induced leaves show up-regulation of PHOR1, an arm repeat protein with homology to the Drosophila segment polarity protein armadillo. Antisense PHOR1 plants are semi-dwarf and show reduced GA responsiveness combined with a higher endogenous content than wild-type plants. PHOR1 was found to be a component of GA signalling pathway that moves to the nucleus in the presence of GA (Amador, et al., 2001). Inter-specific grafting experiments showed that the flower-inducing and the tuberinducing are interchangeable. As CONSTANS gene is the most downstream gene known for the flowering photoperiod pathway and it is known that both the light and the internal clock regulate the accumulation of $\mathrm{CO}$, Salomé Prat carried out experiments for the constitutive overexpression in potato of the Arabidopsis CONSTANSgene and found out that tuberization under short day inductive conditions was impaired. Grafting experiments showed that CONSTANS exerts its inhibitory effect on tuber formation by acting in the leaves, thus interfering with the production or transport of the tuberization stimulus to the underground stolons. Prat and co workers proposed that a conserved photoperiodic functional module, that includes CONSTANS, may be involved in controlling distinct photoperiod responses through the production of long distance acting florigen-tuberigen signal in the leaves (Martínez-García, et al., 2002). For a more detailed vision of Salomé Prat contribution to the understanding of tuber development, see Rodríguez-Falcón et al., (2006) and references therein. Recently, Salomé Prat and co-workers have reported on the central role of the nuclear transcription factor PIF4 (PHYTOCHROME INTERACTING FACTOR 4) in the positive control of genes mediating cell elongation and on the negative regulation of this factor by the light photoreceptor phyB and by DELLA proteins, with a key repressor function in GA-signalling, offering to the reader a molecular framework for light and gibberellin control of cell elongation (De Lucas et al., 2008).

\section{Circadian clock and regulation of development by light}

Paloma Más (Laboratori de Genètica Molecular Vegetal, CSICIRTA, Barcelona) is a very promising scientist belonging to what

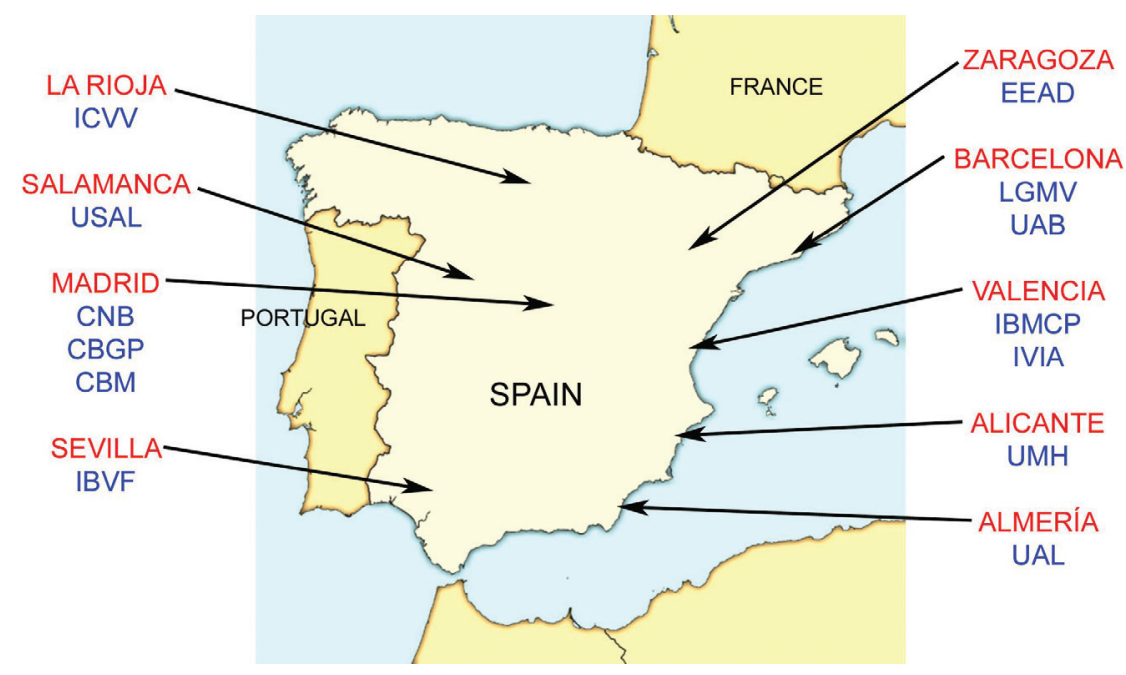

Fig. 5. Localization of the largest Centres of Research devoted to Plant Developmental Biology within the Spanish geography.
I have called the third generation of Spanish plant developmental biologists. While she was working in The Scripps Research Institute with Steve A. Kay, made relevant contributions for the understanding of the molecular bases of the circadian clock in Arabidopsis thaliana. They provided genetic and molecular evidence for the interaction of TIMING OF CAB EXPRESSION1 (TOC1) and ZTL, which is probably responsible for the regulation of circadian period by the clock (Más et al., 2003a). Together with David Alabadí and Steve Kay, they showed that TOC1 plays a dual role in the control of circadian and photomorphogenic responses (Más et al., 2003b). Moreover, Paloma Más was able to show the genetic interaction that occurs between the Arabidopsis photoreceptors phy $B$ and cry 2 in the control of flowering time, hypocotyl elongation and circadian period by the clock (Más etal., 2000). Despite the importance of circadian clock function on plant growth and development, the mechanisms for regulation of oscillator expression remain poorly understood. Paloma Más has established a laboratory in Barcelona devoted to the study the biological clock in Arabidopsis (Perales et al., 2006) and, especially, the molecular basis of the regulation of TOC1 expression. She has shown that the circadian clock regulates the rhythmic changes in histone acetylation-deacetylation at the TOC1 promoter and that the circadian binding of the clock component CIRCADIAN CLOCK ASSOCIATED1 (CCA1) facilitates the reversible switch between a transcriptionally permissive chromatin state and a repressive chromatin compaction at the TOC1 locus (Perales and Más, 2007). Isabel Allona and Cipriano Aragoncillo (Departamento de Biotecnología, U Politécnica de Madrid) have studied the winter disruption of the circadian clock in chesnut (Ramos et al., 2005). They used as marker genes CsTOC1 and $C S L H Y$ which are homologous to essential components of the circadian oscillator in Arabidopsis. Those two genes cycled daily as expected during vegetative growth both in chestnut seedlings and adult plants. During winter dormancy the mRNAs levels of the marker genes were high and did not oscillate. The normal cycle was resumed when endodormant or cold-treated plants were returned to $22^{\circ} \mathrm{C}$. The behaviour of $\mathrm{CsTOC} 1$ and $C S L H Y$ during a cold response revealed an aspect of clock regulation not yet described in Arabidopsis. Jaime Martínez-García (Laboratori de Genètica Molecular Vegetal, CSICIRTA, Barcelona) working with Peter Quail in Berkeley, USA made important contributions for the understanding of transduction of light signals through photoreceptors into photoresponsive genes. They reported that the basic helix-loophelix transcription factor PIF3 binds specifically to a G-Box DNA sequence motif which is present in various light-regulated gene promoters and that phytochrome B binds reversibly to G-box-bound PIF3 specifically upon light-triggered conversion of the photoreceptor to its biologically active form (Martínez-García et al., 2000). Currently, Jaime Martínez-García leads a group that has reported the identification of primary target genes of phytochrome signalling using shade avoidance responses in Arabidopsis as an experimental approach (Roig-Vilanova et al., 2006). Recently, they have functionally characterized $P A R 1$ and $P A R 2$, two Arabidopsis thaliana genes which inte- 
grate shade and hormone transcriptional networks, rapidly connecting phytochrome-sensed light changes with auxin responsiveness (Roig-Vilanova et al., 2007). José A. Jarillo while he was working with Joseph E. Ecker and Anthony Cashmore (U Pennsylvania, USA), studied the molecular bases of chloroplast migration towards illuminated sites to optimize photosynthesis and described that the Arabidopsis NPL 1 gene is required for chloroplast relocation induced by blue light (Jarillo et al., 2001a). Furthermore, he was able to isolate $A D A G / O$, a component of the Arabidopsis circadian system of Arabidopsis, a gene which interacts with the photoreceptors CRYI and PHYB (Jarillo et al., 2001b). Recently, he carried out the functional characterization of ESD1, a protein factor regulating FLC accumulation in Arabidopsis (Martín-Trillo et al., 2006).

\section{Signal transduction and hormone action}

Javier Paz-Ares, a disciple of Francisco García Olmedo UP Madrid and Heinz Saedler, is perhaps the Spanish plant scientist more qualified for leading large plant initiatives. He directed the Departmento de Genética Molecular de Plantas of the Centro Nacional de Biotecnología, CSIC, Madrid and he has coordinated several international and national research programs dealing with functional genomics of transcription factors in Arabidopsis thaliana. Further, one of the most promising Spanish plant scientists, Roberto Solano, initiated his career under the supervision of Javier Paz Ares. A product of the activity of Javier Paz-Ares was the characterization of the $R 2 R 3-M Y B$ regulatory gene family, describing the existence, at that moment, of more than 85 members. That gene family shares with the MADS-box gene family the fact they probably contain more than one hundred members in plants while in organisms from other phyla just a few of them are present (Romero, et al., 1998). These large size gene families, likely contribute to the regulatory flexibility underlying the developmental and metabolic plasticity displayed by plants. During the last years Javier Paz-Ares has focused his research towards signalling during phosphate starvation in plants. He and co workers from the Departamento de Biotecnología U Politécnica de Madrid, cloned At ACP5 coding for a type 5 acid phosphatase that is induced by phosphate starvation and it could be involved in phosphate mobilisation (Del Pozo et al., 1999). Paz-Ares cloned PHR1a MYB transcription factor related to the PSR1gene from Chlamydomonas reinhardtii. Those transcription factors were found to bind as a dimer to an imperfect palindromic sequence. PHR1-binding sequences are present in the promoter of Pi starvation-responsive structural genes, which indicate that this protein acts downstream in the Pi starvation signalling pathway (Rubio et al., 2001). Recently, they have proposed a new mechanism, named mimicry, for the regulation of microRNA activity in plants based on the observation that the non-coding sequence of the gene INDUCED BY PHOSPHATE STARVATION 1 (IPS1) contains a motif with sequence complementarity to the phosphate $(\mathrm{Pi})$ starvation-induced miRNA miR-399. However, the complementary pairing is interrupted by a mismatched loop at the expected miRNA cleavage site. They have shown that IPS1 sequesters instead of being cleaved miR-399, therefore IPS1 overexpression lead to an increased accumulation of the miR-399 target PHO2 mRNA and concomitantly the shoot Pi content is reduced. Engineering of IPS1 to be cleavable abolish its inhibitory activity on miR-399 (Franco-Zorrilla et al., 2007).
Jasmonates are essential phytohormones for plant development. However, the molecular details of their signalling pathway remain unknown. Recently, Roberto Solano (Departmento de Genética Molecular de Plantas of the Centro Nacional de Biotecnología, CSIC, Madrid) has identified JASMONATE-INSENSITIVE 3 and a family of related proteins named JAZ (jasmonate ZIM-domain) as direct targets of the SCF COI1 E3 ubiquitin ligase and that jasmonate treatment induces their proteasome degradation. Further, JAI3 negatively regulates MYC2, the key transcriptional activator of jasmonate responses (Chini, et al., 2007).

David Alabadí (IBMCP, CSIC-UPV, Valencia), who worked together with Miguel Angel Blázquez and José Luis GarcíaMartínez, discovered a role for GAs in the repression of photomorphogenesis in darkness. Plants can undergo two different developmental programs depending on whether they grow in darkness (skotomorphogenesis) or in light (photomorphogenesis). The transition between the two pathways is tightly regulated. Alabadi and co-workers described that Arabidopsis plants with reduced GA levels show characteristics of light-grown plants when grown in darkness, including loss of the apical hook, inhibition of hypocotyl growth, cotyledon opening, and miss-regulation of lightcontrolled genes and proved at the same time that those phenotypes appeared to be conserved among different plant species (Alabadí et al., 2004). Miguel Angel Blázquez (IBMCP, CSICUPV, Valencia), leads a group that has recently showed auxin signalling in Arabidopsis is mediated by the transcriptional regulation of gibberellin metabolism genes (Frigerio et al., 2006). Josep Casacuberta (Laboratori Genètica Molecular Vegetal, Barcelona) has described a putative new mechanism for signalling in maize through atypical receptor protein kinases. That mechanism includes the direct activation of MIK, a center kinase (GCK)-like kinase, by MARK, a maize atypical receptor kinase (Llompart et al., 2003). Juan Carlos del Pozo, while he was working with M. Estelle, USA reported that the auxin response in Arabidopsis depends on the activation of members of the RUB family of ubiquitin- related nuclear proteins (Del Pozo etal., 1998). Monica Pernas while working with José Juan Sánchez-Serrano (Departmento de Genética Molecular de Plantas, CSIC, Centro Nacional de Biotecnología, CSIC, Madrid) has reported that the catalytic subunit of a protein phosphatase $2 \mathrm{~A}$ functions as a negative regulator of abscissic acid signalling, and that ABA antagonistically regulates the expression and the activity of this phosphatase 2A subunit, thus allowing plant sensitivity to the hormone to be stopped after induction (Pernas et al., 2007). Finally, Cristina Ferrándiz (IBMCP CSIC-UPV, Valencia) leads a molecular genetic group currently investigating gynoecium patterning, including the role of auxins and novel genes (Balanzá et al., 2006).

\section{Cell cycle, chromatin modification and plant development}

Crisanto Gutierrez (Centro de Biología Molecular, CSIC, Madrid) has established a laboratory studying the coupling mechanisms between cell proliferation and development in plants (Gutierrez, 2005 and references therein). They have described the role of the retinoblastoma/E2F pathway during Arabidopsis leaf development (Desvoyes et al., 2006). Cell proliferation and cell fate, growth and differentiation, are strictly coupled processes during plant development. The expression pattern of the homeobox 
GLABRA gene determines hair/non-hair cell fate in Arabidopsis root epidermis if both, the appropriate signalling of positional information from the underlying cortical layer is produced, and the complex transcriptional regulation including changes in chromatin accessibility happens. Crisanto Gutierrez investigated the molecular links between the processes described above and cell division. They have identified GEM, a GL2expression modulator as an interactor of CDT1, a DNA replication protein, and shown that GEM participates in the maintenance of the repressor histone $\mathrm{H} 3 \mathrm{H} 9$ methylation status of root patterning genes. This provides a molecular connection between cell division, fate and differentiation during Arabidopsis root development (Caro et al., 2007).

The inheritance of gene transcriptional status depends on the existence of epigenetic chemical modifications in the chromatin and DNA not eliminated during mitosis. Functionally one can distinguish different chromatin modifiers such as histone chaperones, histone modification enzymes and ATP-dependent chromatin remodelling enzymes. José Carlos Reyes, IBVF (Sevilla) has made significant contributions to this area. His group has characterized the Arabidopsisnuclear protein BRAHMA (At BRM) which is homologous to the Brahma ATPase belonging to the SWI/SNF chromatin remodelling complex of Drosophila. By means of RNA interference, they showed that the silenced plants flower earlier than wild-type plants and that the levels of CONSTANS, FT and SOC1 trascripts were up-regulated under non-inductive conditions suggesting that AtBRM is a repressor of the photoperiod-dependent flowering pathway (Farrona et al., 2004). They have also isolated SE, a protein forming part of the SWR1/SRCAP chromatin remodelling complex, which is required for flowering repression (March-Díaz et al., 2007). Teresa Roldán-Arjona (Departamento de Genética, Universidad de Córdoba) has reported the participation of DEMETER (DME) and REPRESSOR OF SILENCING1 (ROS1), two Arabidopsis thaliana genes encoding closely related DNA glycosylase domain proteins, in DNA demethylation. Mutants in DMEor ROS1 have pleiotropic phenotypes, including slow growth, aborted seeds and hypermethylation. (Morales-Ruíz et al., 2006). Progress in the understanding of the regulation of DNA demethylation in plants will open new crucial perspectives in the mechanisms of many developmental processes in the near future.

\section{Concluding remarks}

The last decades have been a flourishing time for the study of Plant Developmental Biology in Spain. From a non-existing discipline, nowadays we have a small but highly qualified community devoted to plant developmental studies. Besides excellent groups of plant developmental biologists established at many universities, several Centres in which excellent progress in plant developmental biology is being accomplished, CNB and CBGP in Madrid, LGMV, CSIC-IRTA in Barcelona, IBMCP, CSIC-UPV in Valencia and IBVF, CSIC-USE in Sevilla are already consolidated in Spain although they still have the potential to grow more. Contributions by Spanish scientists to Plant Developmental Biology appear imbalanced towards molecular biology approaches of reproductive biology despite the vigour of the groups which investigate leaf and other vegetative developmental processes. Molecular genetics, including quantitative genetics approaches are more scarce, while genomic strategies, applied only in part to plant develop- mental processes, has been restricted and with very limited public financial support, to Arabidopsis thaliana, Solanum Lyicopersicon, Cucumis melo, Citrus clementinaand Vitis vinifera. Together with senior scientists already established in Spanish laboratories, the high number of young scientists which have made outstanding contributions to Plant Developmental Biology while they were abroad, just returned or in the process to come back to Spain, make us highly optimistic about the future of this field of research. However, we must provide them with the appropriate conditions to develop their imagination and creativity in order to open new areas of research, incorporate technological breakthroughs into their laboratories and carry out cooperative research by means of networking. The Spanish Plant Developmental Network that groups together the researchers cited in this paper organizes joint meetings, every two years, in which members discuss on common strategies to support Plant Developmental Biology research in Spain. Currently, the Network is coordinated by Jaume MartínezGarcía, Paloma Más, Soraya Pelaz y Pep Casacuberta from LGMV, CSIC-IRTA and the last meeting was programmed for February 2008 in Barcelona.

\section{Please note}

The space available in this review is not sufficient to cover exhaustively the contributions of all scientists whose activities could be considered close to Plant Developmental Biology. The members of the Spanish Network of Developmental Biologists, Ministry of Education and Science, were selected to trace their activities as the core of this scientific community. Even in the case of all scientists mentioned here, it is impossible to cite all their important contributions. The author wants to apologize to all the scientists who think that their work has not been properly recognized in this paper and assumes the responsibility of highlighting their more relevant scientific contributions.

\section{Acknowledgements}

I want to thank Luis Antonio Cañas and Miguel Angel Blázquez from IBMCP, Valencia, Javier Paz-Ares from CNB, Madrid, and Desmond Bradley for the critical reading of the manuscript and their valuable suggestions. Research in the laboratory of the author was financed by Spanish Ministry of Science and Education (BIO2003-01171; BIO200609374 and PTR95-0979-OP-03-01) and from Generalitat Valenciana. Mar Beltrán revised the English version of the manuscript.

\section{References}

ACOSTA, C., PÉREZ-AMADOR, M.A., CARBONELL, J. and GRANELL, A. (2005). The two ways to produce putrescine in tomato are cell-specific during normal development. Plant Sci. 168: 1053-1057.

AGUILAR-MARTínEZ, J.A., POZA, C. and CUBAS, P. (2007). Arabidopsis BRANCHED1 acts as an integrator of branching signals within axillary buds. Plant Cel/ 19: 458-472.

ALABADÍ, D., GIL, J., BLÁZQUEZ, M.A. and GARCÍA-MARTÍNEZ, J.L. (2004). Gibberellins repressphotomorphogenesis in dark. Plant Physiol. 134: 10501057.

ALEJANDRO, S., RODRÍGUEZ, P.L., BELLÉS, J.M., YENUSH, L., GARCÍASANCHEZ, M.J., FERNÁNDEZ, J.A. and SERRANO, R. (2007). An Arabidopsis quiescin-sulfhydryl oxidase regulates cation homeostasis at the root symplastxylem interface. EMBO J. 26: 3203-3215.

ALMOGUERA, C. and JORDANO, J. (1992). Developmental and environmental concurrent expression of sunflower dry-seed-stored low-molecular-weight heatshock protein and Lea mRNAs. Plant Mol. Biol. 19: 781-792.

ALMOGUERA, C., ROJAS, A., DÍAZ-MARTíN, J., PRIETO-DAPENA, P., CARRANCO, R. and JORDANO, J. (2002). A seed-specific heat shock transcription factor involved in developmental regulation during embryogenesis in 
sunflower. J. Biol. Chem. 277: 43866-43872.

ALONSO-BLANCO, C., EL-ASSAL, S. E-D., COUPLAND, G. and KOORNNEEF, M. (1998). Analysis of natural allelic variation at flowering time loci in the Landsberg erecta and Cape Verde islands ecotypes of Arabidopsis thaliana. Genetics 149: 749-764.

ALONSO-BLANCO, C., BLANKESTEIJIN-DE VRIES, H., HANHART, C.J.G., and KOORNNEEF, M. (1999). Natural allelic variation at seed size loci in relation to other life history traits of Arabidopsis thaliana. Proc. Natl. Acad. Sci. USA 96: 4710-4717.

ALONSO-CANTABRANA, H., RIPOLL, J.J., OCHANDO, I., VERA, A., FERRÁNDIZ, C., and MARTÍNEZ-LABORDA, A. (2007). Common regulatory networks in leaf and fruit patterning revealed by mutations in the Arabidopsis ASYMETRIC LEAVES1 gene. Development 134: 2663-2671.

ALONSO-PERAL, M.M., CANDELA, H., DEL POZO, C., MARTÍNEZ-LABORDA, A., PONCE, M.R. and MICOL, J.L. (2006). The HVE/CAND1 gene is required for the early patterning of leaf venation in Arabidopsis. Development 133: 3755 3766 .

AMADOR, V., MONTE, E., GARCíA-MARTínEZ, J.L. and PRAT, S. (2001). Gibberellins signal nuclear import of PHOR1, a photoperiod-responsive protein with homology to Drosophila armadillo. Ce//106: 343-354.

Ausín, I., ALONSO-BLANCO, C., JARILLO, J.A., RUIZ-GARCÍA, L., and MARTÍNEZ-ZAPATER, J.M. (2004). Regulation of flowering time by FVE, a retinoblastoma binding protein. Nature Genetics 36: 162-166.

BALANZA, V., NAVARRETE, M., TRIGUEROS, M. and FERRÁNDIZ, C. (2006).Patterning the female side of Arabidopsis: the importance of hormones. J.Exp.Bot. 57: 3457-3469

BELTRÁN, J.P. (1991). A flourishing time for flower development. The New Biologist 3: 667-670.

BELTRÁN, J.P., FERRÁNDIZ, C., GÓMEZ, M.D., RODRÍGUEZ-CONCEPCIÓN, M., PÉREZ, A., NAVARRO, C., and CAÑAS, L.A. (1996). The use of homeotic mutants to study flower development in Pisum sativum $\mathrm{L}$. Flowering Newsletter 22: 41-48.

BENLLOCH, R., NAVARRO, C., BELTRÁN, J.P. and CAÑAS, L.A. (2003). Floral development of the model legume Medicago truncatula:ontogeny studies as a tool to better characterize homeotic mutations. Sexual Plant Reproduction 15: 231-241.

BENLLOCH, R., d’ERFURTH, I., FERRÁNDIZ, C., COSSON, V., BELTRÁN, J.P., CAÑAS, L.A., KONDOROSI, A., MADUEÑO, F., and RATET, P. (2006). Isolation of mtpim proves Tht1 a useful reverse genetics tool in Medicago truncatula and uncovers new aspects of AP1-like functions in legumes. Plant Physiol. 142: 972-983.

BENLLOCH, R., BERBEL, A., SERRANO-MISLATA, A., and MADUEÑO, F. (2007). Floral initiation and inflorescence architecture: A comparative view. Annals of Botany 100:659-676.

BERBEL, A., NAVARRO, C., FERRÁNDIZ, C., CAÑAS, L.A., MADUEÑO, F., and BELTRÁN, J.P. (2001). Analysis of PEAM4, the AP1 functional homologue, supports a model for $A P$-like genes controlling both floral meristem and floral organ identity in different plant species. Plant J. 25: 441-451.

BERBEL, A., NAVARRO, C., FERRÁNDIZ, C., CAÑAS, L.A., BELTRÁN, J.P. and MADUEÑO, F. (2005). Functional conservation of PISTILLATA activity in a pea homologue lacking the PI domain. Plant Physiol. 142: 972-983.

BERNÁ, G., ROBLES, P. and MICOL, J.L. (1999). A mutational analysis of leaf morphogenesis in Arabidopsis thaliana. Genetics 152: 729-742.

BEVAN, M.W., FLAWELL, R. B. and CHILTON, M.D. (1983). A chimaeric antibiotic resistance gene as a selectable marker for plant cell transformation. Nature 304: 184-187.

BLÁZQUEZ, M.A., SOOWAL, L.N., LEE; I. and WEIGEL (1997). LEAFYexpression and flower initiation in Arabidopsis. Development 124: 3835-3844.

BLÁZQUEZ, M.A., GREEN, R., NILSSON, O., SUSSMAN, M.R. and WEIGEL, D. (1998). Gibberellins promote flowering of Arabidopsis by activating the $\angle E A F Y$ promoter. Plant Cel/ 10: 791-800.

BUSK, P.K. and PAGES, M. (1997). Protein binding to the abscisic acid responsive element is independent of viviparous1 in vivo. Plant Cel/9: 2261-2270.

CALONJE, M., CUBAS, P., MARTÍNEZ-ZAPATER, J.M. and CARMONA, M.J. (2004). Floral meristem identity genes are expressed during tendril development in grapevine. Plant Physiol. 135: 1491-1501.
CARMONA, M.J., CUBAS, P. and MARTÍNEZ-ZAPATER, J.M. (2002). VFL, the grapevine FLORICAULA/LEAFY ortholog, is expressed in meristematic regions independently of their fate. Plant Physiol. 130: 68-77.

CARMONA, M.J., CALONJE, M. and MARTÍNEZ-ZAPATER; J.M. (2007). The FT/ TFL1 gene family in grapevine. Plant Mol. Biol. 63:637-650.

CARO, E., CASTELLANO, M.M. and GUTIÉRREZ, C. (2007). A chromatin link that couples cell division to root epidermis patterning in Arabidopsis. Nature 447: 213-217.

CHILTON, M.D., DRUMMOND, M.H., MERLO, D.J., SCIAKY, D., MONTOYA, A.L., GORDON, M.P. and NESTER, E.W. (1977). Stable incorporation of plasmid DNA into higher plant cells: the molecular basis of crown gall tumorigenesis. Cell 11: 263-271.

CHINI, A., FONSECA, S., FERNÁNDEZ, G., ADIE, B., CHICO, J.M., LORENZO, O., GARCÍA-CASADO, G., LÓPEZ-VIDRIERO, I., LOZANO, F.M., PONCE, M.R., MICOL, J.L., and SOLANO, R. (2007). The JAZ family of repressors is the missing link in jasmonate signalling. Nature 448: 666-671.

COEN, E.S., ROMERO, J.M., DOYLE, S., ELLIOTT, R., MURPHY, G. and CAR PENTER, R. (1990). Floricaula: a homeotic gene required for flower development in Antirrhinum majus. Cel/63: 1311-1322.

COEN, E.S. and MEYEROWITZ, E.M. (1991). The war of the whorls: Genetic interactions controlling flower development. Nature 353: 31-37.

CUBAS, P., COEN, E. and MARTÍNEZ-ZAPATER, J.M. (2001). Ancient asymetries in the evolution of flowers. Current Biology 11: 1050-1052.

CUBAS, P., VINCENT, C. and COEN, E. (1999). An epigenetic mutation responsible for the natural variation in floral symmetry. Nature 401: 157-161.

DAVIES, B., EGEA-CORTINES, M., SILVA, E.D, SAEDLER, H. and SOMMER, H. (1996). Multiple interactions amongst floral homeotic Mads Box Proteins. EMBO J. 15: 4330-4343.

DE LUCAS, M., DAVIÈRE, J-M., RODRÍGUEZ-FALCÓN, M., PONTIN, M., IGLESIAS-PEDRAZ, J.M., LORRAIN, S., FRANKHAUSER, C., BLÁZQUEZ, M.A., TITARENKO, E., and PRAT, S. (2008). A molecular framework for light and gibberellin control of cell elongation. Nature (in press).

DEL POZO, J.C., ALLONA, I., RUBIO, V., LEYVA, A., ARAGONCILLO, C., DE LA PEÑA, A. and PAZ-ARES, J. (1999). A type 5 acid phosphatase gene from Arabidopsis thaliana is induced by a phosphate starvation and by some other types of phosphate mobilising/oxidative stress conditions. Plant J. 19:579-590.

DEL POZO, J.C., BONIOTTI, M.B. and GUTIÉRREZ, C. (2002). Arabidopsis E2Fc functions in cell division and is degraded by the ubiquitin-SCFAtSKP2 pathway in response to light. Plant Cel/14: 3057-3071.

DESVOYES, B., RAMÍREZ-PARRA, E., XIE, Q., CHUA, N.-H. and GUTIÉRREZ, C (2006). Cell type-especific role of the retinoblastoma/E2F pathway during Arabidopsis leaf development. Plant Physiol. 140: 67-80.

DÍAZ, I., VICENTE-CARBAJOSA, J., ABRAHAM, Z., MARTÍNEZ, M., ISABEL-LA MONEDA, I. and CARBONERO, P. (2002). The GAMYB protein from barley interacts with the DOF transcription factor BPBF and activates endospermspecific genes during seed development. Plant J. 29: 453-464.

DOMíMGUEZ, F., MORENO, J. and CEJUDO, J. (2004). A gibberellin-induced nuclease is localized in the nucleus of wheat aleurone cells undergoing programmed cell death. J. Biol. Chem. 279: 11530-11536.

EGEA-CORTINES, M., SAEDLER, H. and SOMMER, H. (1999). Ternary complex formation between the Mads-box Proteins Squamosa, Deficiens and Globosa is involved in the control of floral architecture in Antirrhinum Majus. EMBO J. 18 (19): 5370-5379.

EL-ASSAL, S.E-D., ALONSO-BLANCO,C., PEETERS, A.J.M., RAZ, V and KOORNNEEF, M. (2001). A QTL for flowering time in Arabidopsis reveals a novel allele of CRY2. Nature Genetics 29: 435-440.

ENJUTO, M., LUMBRERAS, V., MARÍN, C., and BORONAT, A. (1995). Expression of the Arabidopsis HMG2 gene, encoding 3-hydroxy-3-methylglutaryl coenzyme $\mathrm{A}$ reductase, is restricted to meristematic and floral tissues. Plant Cel/7: 517-527.

ESTRUCH, J.J. and BELTRÁN, J.P. (1991). Gibberellic acid stimulates acid invertase secretion in pea ovary protoplasts. FEBS Lett. 279: 303-306.

FARRONA, S., HURTADO, L., BOWMAN, J. and REYES, J.C. (2004). The Arabidopsis thaliana SNF2 homolog AtBRM controls shoot development and flowering. Development 131: 4965-4975. 
FERRÁNDIZ, C., NAVARRO, C., GÓMEZ, M.D., CAÑAS, L.A. and BELTRÁN, J.P. (1999a). Flower development in Pisum sativum: from the war of the whorls to the battle of the common primordia. Dev. Genet. 25: 280-290.

FERRÁNDIZ, C., PELAZ, S., YANOFSKI, M.F. (1999b). Control of carpel and fruit development in Arabidopsis. Annu. Rev. Biochem. 68: 321-354.

FERRÁNDIZ, C., LILJEGREN, S.J. and YANOFSKY, M.F. (2000a). Negative regulation of the SHATTERPROOF genes by FRUITFULL during Arabidopsis fruit development. Science 289: 436-438.

FERRÁNDIZ, C., GU, Q., MARTIENSSEN, R. and YANOFSKY, M.F. (2000b). Redundant regulation of meristem identity and plant architecture by FRUITFULL, APETALA1 and CAULIFLOWER. Development 127: 725-734.

FOS, M., NUEZ, F., and GARCÍA-MARTíNEZ, J.L. (2000). The gene pat-2, which induces natural parthenocarpy, alters the gibberellin content in unpollinated tomato ovaries. Plant Physiol. 122: 471-479.

FRANCO-ZORRILLA, J.M., VALLI, A., TODESCO, M., MATEOS, I., PUGA, M.I., RUBIO-SOMOZA, I., LEYVA, A., WEIGEL, D., GARCÍA, J.A. and PAZ-ARES, J. (2007). Target mimicry provides a new mechanism for regulation of microRNA activity. Nature Genetics 39: 1033-1037.

FRIGERIO, M., ALABADI, D., PEREZ-GÓMEZ, J., GARCÍA-CARCEL, L., PHILLIPS, A.L., HEDDEN, P. and BLAZQUEZ, M.A. (2006). Transcriptional regulation of gibberellin metabolism genes by auxin signalling in Arabidopsis. Plant Physiol. 142: 553-563.

GARCÍA-MARTÍNEZ, J.L. and CARBONELL, J. (1980). Fruit-set of un-pollinated ovaries of Pisum sativumL. - influence of plant-growth regulators. Planta 147: 451-456.

GARCÍA-MARTÍNEZ, J.L. and BELTRÁN, J.P. (1992). Interaction between vegetative and reproductive organs during early fruit development in pea. In Progress in Plant Growth Regulation. C.M. Karssen, L.C. Van Loon and D. Vreugdenhil eds (Kluwer Acad.Publ) pp, 401-410.

GARCÍA-MARTÍNEZ, J.L., LÓPEZ-DÍAZ, I., SÁNCHEZ-BELTRÁN, M.J., WARD, D.A., PHILLIPS, A.L. and HEDDEN, P. (1997). Isolation and transcript analysis of gibberellin 20 oxidase genes in pea and bean in relation to fruit development. Plant Mol. Biol. 33: 1073-1084.

GARCÍA OLMEDO, F. (2004). Bioquímica y Biología Molecular de plantas. En Cuarenta años de la Sociedad Española de Bioquímica y Biología Molecular (1963-2003) pp.175-188. Eds. Santesmases, M.J., Romero, A. y Avila, J Elecé, 2004. Madrid.

GARCÍA-PONCE DE LEÓN, B., FRANCO-ZORRILLA, J.M., RUBIO, V., DAHIYA, P., PAZ-ARES, J. and LEYVA, A. (2004). Interallelic complementation at the Arabidopsis CRE1 locus incovers independent pathways for the proliferation of vascular initials and canonical cytokinin signalling. Plant J. 38: 70-79.

GODAY, A., JENSEN, A., CULIAÑEZ-MACIÀ, F.A., ALBÀ, M.M., FIGUERAS, M., SERRATOSA, J., TORRENT, M. and PAGĖS, M. (1994). The maize abscisic acid responsive protein rab17 is located in the nucleus and cytoplasm and interacts with nuclear localization signals. Plant Ce//6: 351-360.

GÓMEZ, E., ROYO, J., GUO, Y., THOMPSON, R. and HUEROS, G. (2002). Estabishment of cereal endosoerm expression domains: identification and properties of a maize transfer cell-specific transcription factor, ZmMRP-1. Plant Cel/14: 599-610.

GÓMEZ, J., SÁNCHEZ-MARTÍNEZ, D., STIEFEL, V., RIGAU, J., PUIGDOMĖNECH, P. and PAGĖS, M. (1988). A gene induced by the plant hormone abscisic acid in response to water stress encodes a glycine-rich protein. Nature 334:262-264.

GÓMEZ-MENA, C., PIÑEIRO, M., FRANCO-ZORRILLA, J.M., SALINAS, J. COUPLAND, G. and MARTÍNEZ-ZAPATER, J.M. (2001). Early bolting in short days: An Arabidopsis mutation that causes early flowering and partially suppresses the floral phenotype of leafy. Plant Cel/13: 1011-1024.

GONZÁLEZ-GARCíA, M.P., RODRÍGUEZ, D., NICOLAS, C., RODRÍGUEZ, P.L, NICOLAS, G., and LORENZO, O. (2003). Negative regulation of ABA-signaling by the Fagus sy/vaticaFsPP2C1 plays a role in seed dormancy regulation and promotion of seed germination. Plant Physiol. 133: 135-144.

GRANELL, A., HARRIS, N., PISABARRO, A.G. and CARBONELL, J. (1992).Temporal and spatial expression of a thiolprotease gene during pea ovary senescence, and its regulation by gibberellin. Plant J. 2: 907-915.

GUTIÉRREZ, C. (2005). Coupling cell proliferation and development in plants. Nature Cell Biol. 7: 535-541.

HECHT, V., FOUCHER, F., FERRÁNDIZ, C., MACKNIGHT,R., NAVARRO, C.,
VARDY, M.E., ELLIS, N., BELTRÁN, J.P., RAMEAU, and C., WELLER, J.L. (2005). Conservation of Arabidopsis flowering genes in model legumes. Plant Physiol. 137: 1420-1434.

HERRERO, M. (2003). Male-female synchrony and the regulation of mating in flowering plants. Philosophical Transactions of the Royal Society. Biological Sciences 358: 1019-1024.

JANHKE, S., BIER, D., ESTRUCH, J. J., and BELTRAN, J.P. (1989). Distribution of photoassimilates in the pea plant: chronology of events in non fertilized ovaries and effects of gibberellic acid. Planta $180: 53-60$

JARILLO, J.A., CAPEL, J., TANG, R.H., YANG, H.Q., ALONSO, J.M., ECKER, J.R., and CASHMORE, A.R. (2001). An Arabidopsis circadian clock component interacts with both CRY1 and PhyB. Nature 410: 487-490.

JARILLO, J.A, GABRYS, H., CAPEL, J., ALONSO, J.M., ECKER, J.R., and CASHMORE, A.R. (2001). Phototropin-related NPL1 controls blue light-induced chloroplast recolocation. Nature 410: 952-954.

JOSÉ-ESTAÑOL, M., RUIZ-ÁVILA, L. and PUIGDOMĖNECH, P. (1992). A maize embryo-specific Gene encodes a proline-rich and hydrophobic Protein. Plant Cel/ $4:$ : 413-423.

KEURENTJES, J.J.B., BENTSINK, L., ALONSO-BLANCO, C., HANHART, C.J., BLANKESTIJN-DE VRIES, H., EFFGEN, S., VREUGDENHIL, D. and KOORNNEEF, M. (2007). Development of a near-isogenic line population of Arabidopsis thaliana and comparison of mapping power with a recombinant inbred line population. Genetics 175: 891-905.

LEYVA, A., LIANG, X., PINTOR-TORO, J.A., DIXON, R.A. and LAMB, C.J. (1992). Cis-Element combinations determine phenylalanine ammonia-lyase gene tissue-specific expression patterns. Plant Cel/ 4: 263-271.

LLOMPART, B., CASTELLS, E., RÍO, A., ROCA, R., FERRANDO, A., STIEFEL, V. PUIGDOMĖNECH, P. and CASACUBERTA, J.M. (2003). The direct activation of MIK, a GCK-like kinase, by MARK, a maize atypical receptor kinase, suggests a new mechanism for signaling through dead-kinase receptors. J. Biol. Chem. 278: 48105-48111.

LOIS, L.M., RODRÍGUEZ-CONCEPCIÓN, M., GALLEGO, F., CAMPOS, N. and BORONAT, A. (2000). Carotenoid biosynthesis during tomato fruit development: regulatory role of 1 -deoxy-D-xylulose 5-phosphate synthase. Plant J. 22 : 503-514.

LOZANO, R., ANGOSTO, T., GÓMEZ, P., PAYÁN, C., CAPEL, HUIJSER, P., SALINAS, J. and MARTÍNEZ-ZAPATER, J.M. (1998). Tomato flower abnormalities induced by low temperatures are associated to changes of expression of MADS-box genes. Plant Physiol. 117: 91-100.

MADUEÑO, F., BERBEL, A., BELTRAN, J.P. and FERRÁNDIZ, C. (2006). On the origin of the complex inflorescence of legumes: the role of a new MADS-box gene in inflorescence meristem identity. XV FESPB Congress. Federation of European Societies of Plant Biology, pp42.

MARCH-DÍAZ, R., GARCÍA-DOMÍNGUEZ, M., FLORENCIO, F.J. and REYES, J.C. (2007). SEF, a New Protein Required for the Flowering Repression in Arabidopsis, Interacts with PIE1 and ARP6. Plant Physiol. 143: 893-901.

MARTí, C., CUBELLS, X., ELLUL, P., MORENO, V., CARBONELL, J., ORZÁEZ, D. and GRANELL, A. (2007). A single DELLA gene controls fruit set and early fruit development in tomato. Plant J. 52: 865-876.

MARTÍN-TRILLO, M., LÁZARO, A., SCOTT POETHIG, R., GÓMEZ-MENA, C., PIÑEIRO, M.A., MARTÍNEZ-ZAPATER, J.M. and JARILLO, J.A. (2006). Early in short days 1 (ESD1) encodes ACTIN-RELATED PROTEIN 6 (AtARP6), a putative component of chromatin remodelling complexes that positively regulates FLC accumulation in Arabidopsis. Development 133: 1241-1252.

MARTÍNEZ, C., PONS, E., PRATS, G. and LEÓN, J. (2004). Salicylic acid regulates flowering time and links defense responses and reproductive development. Plant J. 37: 209-217.

MARTÍNEZ-GARCÍA, J., HUQ, E. and QUAIL, P. (2000). Direct targeting of light signals to a promoter-element-bound transcription factor. Science 288: 859863.

MARTÍNEZ-GARCÍA, J.F., VIRGÓS-SOLER, A. and PRAT, S. (2002). Control of photoperiod-regulated tuberization in potato by the Arabidopsis flowering-time gene CONSTANS. Proc. Natl. Acad. Sci. USA 99: 15211-15216.

MARTÍNEZ-ZAPATER, J.M., JARILLO, J.A., CRUZ-ÁLVAREZ, M., ROLDÁN, M and SALINAS, J. (1995). Arabidopsis late flowering fve mutants are affected in both vegetative and reproductive development. Plant J. 7: 543-551. 
MARTÍNEZ-ZAPATER, J.M., COUPLAND, G., DEAN, C. and KOORNNEEF, M. (1994). The transition to flowering in Arabidopsis. In Arabidopsis, E.M. Meyerowitz and C.R. Somerville, eds (New York: Cold Spring Harbor Laboratory Press) pp, 403-434.

MÁS, P., DEVLIN, P.F., PANDA, S. and KAY, S.A. (2000). Functional interaction of phytocrome B and cryptochrome 2. Nature 408: 207-211.

MÁS, P., ALABADÍ, D., YANOVSKY, M.J., OYAMA, T. and KAY, S.A. (2003b). Dual role of TOC1 in the control of circadian and photomorphogenic responses in Arabidopsis. Plant Cel/15: 223-236.

MÁS, P., KIM, W.J., SOMERS, D.E. and KEY, S.A. (2003a). Targeted degradation of TOC1 by ZTL modulates circadan function in Arabidopsis. Nature 426: $567-$ 570.

MENA, M., AMBROSE, B., MEELEY, B., BRIGGS, S., YANOFSKY, D. and SCHMIDT, R.J. (1996). Diversification of C-function activity in maize flower development. Science 274: 1537-1540.

MOLINERO-ROSALES, N., JAMILENA, M., ZURITA, S., GÓMEZ, P., CAPEL, P and LOZANO, R. (1999). /FALSIFLORA/, the tomato orthologue of / FLORICAULA/ and /LEAFY/ controls flowering time and flora meristem identity. Plant J. 20: 685-693.

MORALES-RUÍZ, T., ORTEGA-GALISTEO, A.P., PONFERRADA-MARÍN, M.I., MARTÍNEZ-MACÍAS, M.I., ARIZA, R.R. and ROLDÁN-ARJONA, T. (2006). DEMETER and REPRESSOR OF SILENCING1encode 5-methylcytosine DNA glycosidases. Proc. Natl. Acad. Sci. USA 103: 6853-6858.

MORENO-RISUEÑO, A., DÍAZ, I., CARRILLO, L., FUENTES, R. and CARBONERO, P. (2007). The HvDOF19 transcription factor medates the abscisic aciddependent repression of hydrolase genes in germinating barley aleurone. Plant J. 51: 352-365.

ORZÁEZ, D. and GRANELL, A. (1997). DNA fragmentation is regulated by ethylene during carpel senescence in Pisum sativum. Plant J. 11: 137-144.

ORZÁEZ, D., MIRABEL, S., WILEMEIN, W. and GRANELL, A. (2006). Agroinjection of tomato fruits: a tool for rapid functional analysis of transgenes directly in fruit. Plant Physiol. 140: 3-11.

PARCY, F. (2005). Flowering: a time for integration. Int. J. Dev. Biol. 49: 585-593.

PAZ-ARES, J., GHOSAL,D., WIENAND, U., PETERSON, P.A. and SAEDLER, H. (1987). The regulatory $c 1$ locus of Zea mays encodes a protein with homology to myb proto-oncogene products and with structural similarities to transcriptional activators. EMBO J. 6: 3553-3558.

PELAZ, S., DITTA, G.D., BAUMANN, E., WISMAN, E. and YANOFSKY, M.F. (2000). B and C floral organ identity functions require SEPALLATA MADS-box genes. Nature 405: 200-203.

PEÑA, L., MARTÍN-TRILLO, M., JUÁREZ, J., PINA, J.A., NAVARRO, L. and MARTÍNEZ-ZAPATER, J.M. (2001). Constitutive expression of Arabidopsis $\angle E A F Y$ or $A P E T A L A 1$ genes in Citrus reduces their generation time. Nature Biotech. 19: 263-267.

PERALES, M., PORTOLÉS, S. and MÁS, P. (2006). The proteasome-dependent degradation of CKB4 is regulated by the Arabidopsis biological clock. Plant J. 46: 849-860.

PERALES, M. and MÁS, P. (2007). A functionallink betweenrhythmic changes in chromatin structure and the Arabidopsis biological clock. Plant Cel/ 19: 21112123

PERETÓ, J.G. and BELTRÁN, J.P. (1987). Hormone directed sucrose transport during fruit set induced by gibberellins in Pisum sativum. Physiol. Plant.69: 356360.

PÉREZ AMADOR, M.A., CARBONELL, J., and GRANELL, A. (1995). Expression of arginine decarboxylase is induced during early fruit-development and in young tissues of Pisum-Sativum (L). Plant Molecular Biology 28: 997-1009.

PÉREZ-PÉREZ, J.M., SERRANO-CARTAGENA, J. and MICOL, J.L. (2002). Genetic analysis of natural variations in the architecture of vegetative leaves in Arabidopsis thaliana. Genetics 162: 893-915.

PERNAS, M., GARCÍA-CASADO, G., ROJO, E., SOLANO, R., and SANCHEZSERRANO, J.J. (2007). A protein phosphatase $2 A$ catalytic subunit is a negative regulator of abscissic acid signalling. Plant $J$. doi 10.111/j.1365313x.2007.03179-x.

PIÑEIRO, M., GÓMEZ-MENA, C., SCHAFFER, R., MARTÍNEZ-ZAPATER, J.M., and COUPLAND, G. (2003). EARLY BOLTING IN SHORT DAYS is related to chromatin remodeling factors and regulates flowering in Arabidopsis by re- pressing FT. Plant Cel/15: 1552-1562

RAMOS, A., PÉREZ-SOLÍS, E., IBÁÑEZ, C., CASADO, R., COLLADA, C., GÓMEZ L., ARAGONCILLO, C., and ALLONA, I. (2005). Winter disruption of the circadian clock chestnut. Proc. Natl. Acad. Sci. USA 102: 7037-7042.

RIPOLL, J.J., FERRÁNDIZ, C., MARTÍNEZ-LABORDA, A., and VERA, A. (2006). PEPPER, a novel K-homology domain gene, regulates vegetative and gynoecium development in Arabidopsis. Development 289: 346-259.

ROBLES, P. and PELAZ, S. (2005). Flower and fruit development in Arabidopsis thaliana. Int. J. Dev.Biol. 49: 633-643.

RODRÍGUEZ-CONCEPCIÓN, M. and BELTRÁN, J.P. (1995). Repression of the pea lipoxygenase loxg is associated with carpel development. Plant Mol. Biol. 27: 887-899.

RODRÍGUEZ-CONCEPCIÓN, M., FORÉS, O., MARTÍNEZ-GARCÍA, J., GONZÁLEZ-V, J., PHILLIPS, M.A., FERRER, A. and BORONAT, A. (2004). Distinct light-mediated pathways regulate the biosynthesis and exchange of isoprenoid precursors during Arabidopsis seedling development. Plant Ce//16: 144-156.

RODRÍGUEZ-CONCEPCIÓN, M., PÉREZ, A. and BELTRÁN, J.P. (2001). Upregulation of genes encoding novel extracellular proteins during fruit set in pea. Plant Mol. Biol. 46: 373-382.

RODRÍGUEZ-FALCÓN, M., BOU, J. and PRAT, S. (2006). Seasonal control of tuberization in potato: Conserved elements with the flowering response.'Ann Rev. Plant. Biol. 57: 151-180.

ROIG-VILLANOVA, I., BOU, J., SORIN, C., DEVLIN, P.F. and MARTÍNEZ-GARCÍA J.F. (2006). Identification of primary target genes of phytochrome signalling. Early transcriptional control during shade avoidance responses in Arabidopsis. Plant Physiol. 141: 85-96.

ROIG-VILLANOVA, I., BOU-TORRENT, J., GALSTYAN, A., CARRETERO-PAULET, L., PORTOLES, S., RODRÍGUEZ-CONCEPCIÓN, M., and MARTÍNEZ-GARCÍA, J.F. (2007). EMBO J. 26: 4756-4767

ROMERO, I., FUERTES, A., BENITO, M.J., MALPICA, J.M., LEYVA, A. and PAZARES, J. (1998). More than 80 R2R3-MYB regulatory genes in the genome of Arabidopsis thaliana. Plant J. 14: 273-284.

RUBIO, V., LINHARES, F., SOLANO, R., MARTÍN, A.C., IGLESIAS, J., LEYVA, A. and PAZ-ARES, J. (2001). An evolutionary conserved MYB transcription factor involved in phosphate starvation signaling both in vascular plants and in unicellular algae. Genes\&Development 15: 2122-2133.

RUIZ-ÁVILA, L., BURGESS, S., STIEFEL, V., LUDEVID, M.D. and PUIGDOMĖNECH, P. (1992). Accumulation of cell wall hydroxyproline-rich glycoprotein gene mRNA is an early event in maize embryo cell differentiation. Proc. Natl. Acad. Sci. USA 89: 2414-2418.

RUIZ-GARCíA, L., MADUEÑO, F., WILKINSON, M., HAUGHN, G.W., SALINAS, J. and MARTÍNEZ-ZAPATER, J.M. (1997). Different roles of flowering time genes in the activation of floral initiation genes. Plant Cel/9: 1921-1934.

SAEZ, A., ROBERT, N., MAKTABI, H., SCHROEDER, J.I., SERRANO, R.and RODRÍGUEZ, P.L. (2006). Enhancement of Abscisic acid sensitivity and reduction ofwater consumption in Arabidopsis by combined inactivation of the protein phosphatases type 2C ABI1 and HAB1. Plant Physiol. 141: 1389-1399.

SAURET-GÜETO, S., BOTELLA-PAVÍA, P., FLORES-PÉREZ, U., MARTÍNEZGARCÍA, J.F., SAN ROMÁN, C., LEÓN, P., BORONAT, A. and RODRÍGUEZCONCEPCIÓN, M. (2006). Plastid cues post-transcriptionally regulate the accumulation of the key enzymes of the methylerythritol phosphate pathway in Arabidopsis. Plant Physiol. 141: 75-84.

SCHULTZ, E. and HAUGHN, G. (1991). LEAFY, a homeotic gene that regulates inflorescence development in Arabidopsis. Plant Cel/3: 771-781.

SERNA, L. and FENOLL, C. (1997). Tracing the ontogeny of stomatal clusters in Arabidopsis with molecular markers. Plant J. 12: 747-755.

SERNA, L., TORRES-CONTRERAS, J., and FENOLL, C. (2002). Clonal analysis of stomatal development and patterning in Arabidopsis leaves. Dev. Biol. 241: 24-33. .

SOMMER, H., BELTRÁN, J.P., HUIJSER, P., PAPE, H., LÖNNIG, W. E., SAEDLER, H., and SCHWARZ-SOMMER, Z. (1990). DEFICIENS, a homeotic gene involved in the control of flower morphogenesis in Antirrhinum majus: the protein has homology to transcription factors. EMBO J. 9: 605-613

SOMERVILLE, C. and KOORNNEEF, M. (2002). A fortunate choice: the history of Arabidopsis as a model plant. Nature Rev. Genet. 3: 883-889. 
STIEFEL, V., LÓPEZ BECERRA, E., ROCA, R., BASTIDA, M., JARHMANN, T., GRAZIANO, E. and PUIGDOMĖNECH, P. (1999). TM20, a new class of transmembrane proteins expressed in meristematic tissues of Zea mays. J. Biol. Chem. 4: 27734-27739.

SUÁREZ-LÓPEZ, P., WHEATLEY, K., ROBSON, F., ONOUCHI, H., VALVERDE, F. and COUPLAND, G. (2001). CONSTANS mediates between the circadian clock and the control of flowering in Arabidopsis. Nature 410: 1116-1120.

TORNERO, P., CONEJERO, V. and VERA, P. (1996). Phloem specific expression of a plant homeobox gene during secondary phases of vascular development. Plant J. 9: 639-648.

VAN LIJSEBETTENS, M. and VAN MONTAGU, M. (2005). Historical perspectives on plant developmental biology. Int. J. Dev. Biol. 49: 453-465.

VALVERDE, F., MOURADOV, A., SOPPE, W., RAVENSCROFT, D., SAMACH, A. and COUPLAND, G. (2004). Photoreceptor regulation of CONSTANS protein in photoperiodic flowering. Science 303: 1003-1006.

VELlosillo, T., MARTíNEZ, M., LÓPEZ, M.A., VICENTE, J., CASCÓN, T.,
DOLAN, L., HAMBERG, M. and CASTRESANA, C. Oxylipins produced by the 9-lipoxygenase pathway regulate lateral root development and defense re sponses through a novel signalling cascade. Plant Cel/19.

WEBER, A.P.M., WEBER, K.L., CARR, K., WILKERSON, C. and OHLROGGE (2007). Sampling the Arabidopsis transcriptome with massively paralle pyrosequencing. Plant Physiol. 144: 32-42.

WEIGEL, D., ALVAREZ, J., SMYTH, D.R., YANOFSKY, M.F. and MEYEROWITZ, E.M. (1992). $\angle E A F Y$ controls floral meristem identity in Arabidopsis. Cel/ 69 843-859.

WEISS, J., DELGADO-BENARROCH, L. and EGEA-CORTINES, M. (2005). Genetic control of floral size and proportions. Int. J. Dev. Biol. 49: 513-525.

ZAMBRYSKI, P., JOOS, H., GENETELLO, C., LEEMANS, J., VAN MONTAGU, M. and SCHELL, J. (1983). Ti plasmid vector for the introduction of DNA into plant cells without alteration of their normal regeneration capacity. EMBO J. 2:2143 2150 .

\section{Further Related Reading, published previously in the Int. J. Dev. Biol.}

See our Special Issue Plant Development edited by José Luis Micol and Miguel Angel Blázquez at: http://www.ijdb.ehu.es/web/contents.php?vol=49\&issue=5-6

See our recent Special Issue Fertilization, in honor of David L. Garbers and edited by Paul M. Wassarman and Victor D. Vacquier at: http://www.ijdb.ehu.es/web/contents.php?vol=52\&issue=5-6

Vol. 50 Nos. 2/3 (2006)

Developmental Morphodynamics

Vol. 47 Nos. $2 / 3$ (2003)

Teaching Developmental Biology
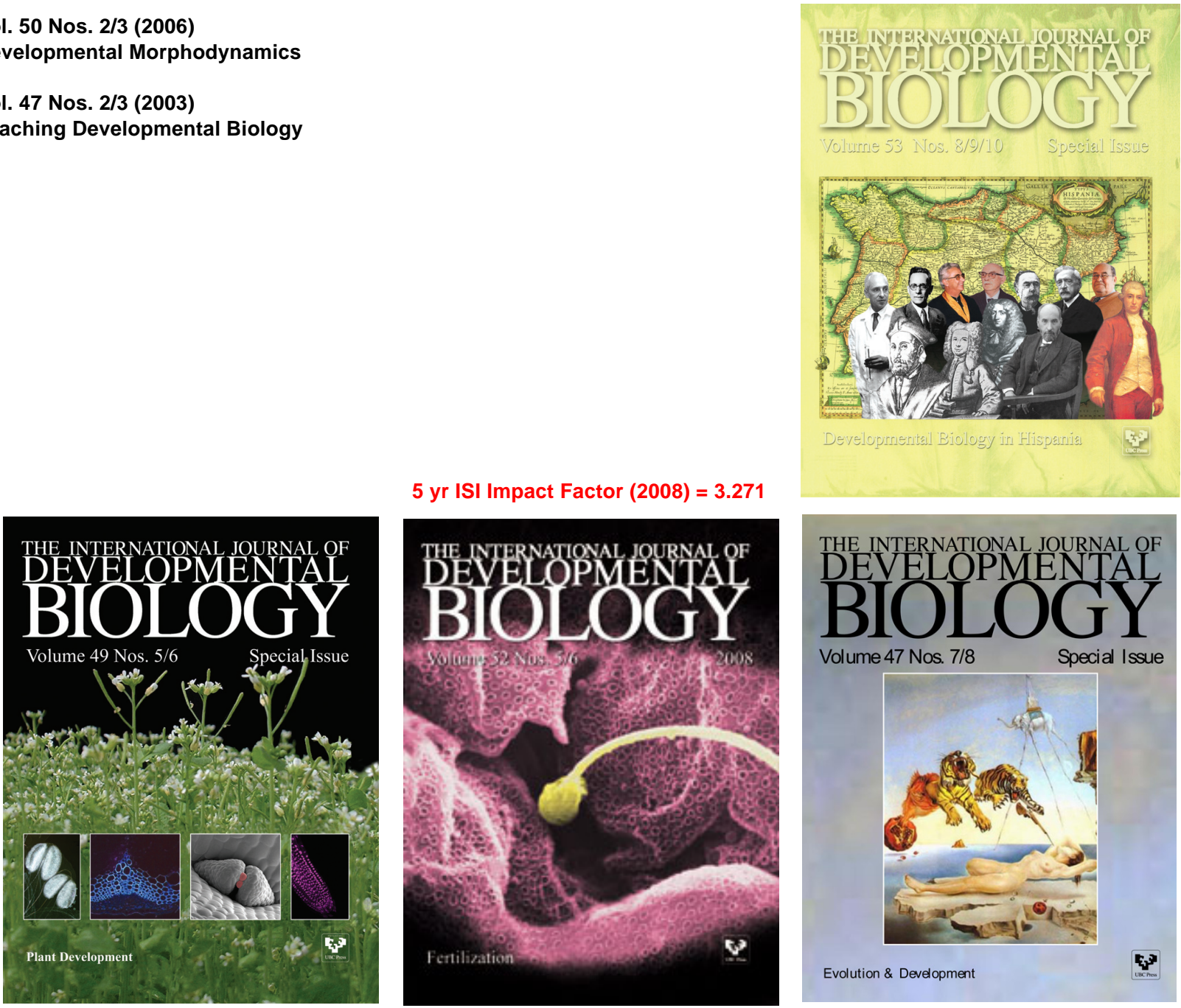

5 yr ISI Impact Factor $(2008)=3.271$
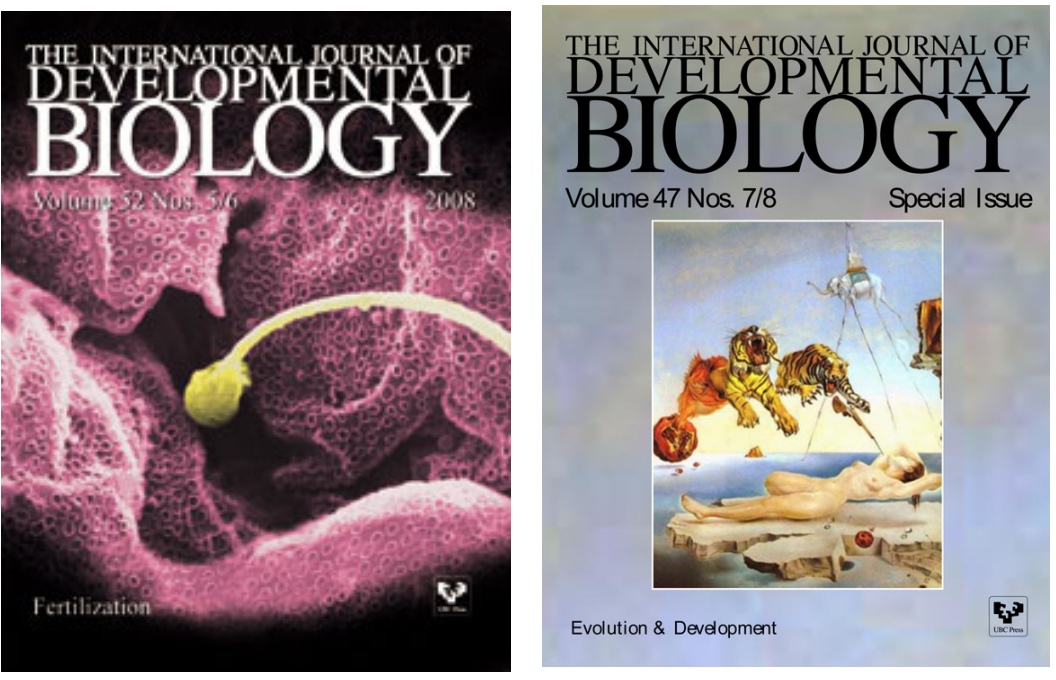